\title{
UNCLASSIFIED
}

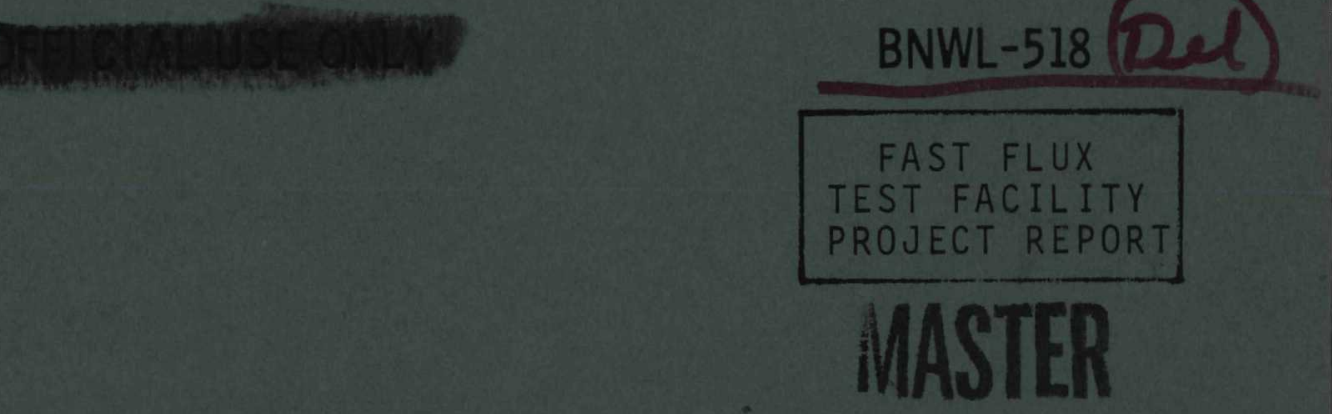

\section{SURVEY OF HYDRAULIC MODELING EXPERIENCE FOR REACTOR CORE SYSTEMS}




\section{DISCLAIMER}

Portions of this document may be illegible in electronic image products. Images are produced from the best available original document. 
PATENT STATUS

This document copy, since it is transmitted in advance of patent clearanee, is made available in confidence solely for use in performance- of work under confracts with the U. S. Afomic Energy Commission. This document is not to be published nor its-contents otherwise disseminated or used for purposes other than specified above before patent approval for suchrelease or use has been secured, upon request, from the Chief, Chicago Patent Group, U. S. Atomic Energy Commisstonn 9800 So. Cass Ave., Argonne, Illinois.

\title{
PRELIMINARY REPORT
}

This report contains information of a preliminary nature prepared in the course of work under Atomic Energy Commission Contract AT(45-1)-1830. This information is subject to correction or modificafion upon the collection and evaluation of additional data.

\section{LEGAL NOTICE}

This report was prepared as an account of Government sponsored work. Neither the United States, nor the Commission, nor any person acting on behalf of the Commission:

A. Makes any warranty or representation, expressed or implied, with respect to the accuracy, completeness, or usefulness of the information contained in this report, or that the use of any information, apparatus, method, or process disclosed in this report may not infringe privately owned rights; or

B. Assumes any liabilities with respect to the use of, or for damages resulting from the use of any information, apparatus, method, or process disclosed in this report,

As used in the above, "person acting on behalf of the Commission" includes any employee or contractor of the Commission, or employee of such contractor, to the extent that such employee or confractor of the Commissios, or employee of such contractor prepares, disseminates, or provides access to any information pursuant to his employment or contract with the Commission, or his employment with such contractor.

\author{
PACIFIC NORTHWEST LABORATORY \\ RICHLAND, WASHINGTON \\ operated by \\ BATTELLE MEMORIAL INSTITUTE \\ for the \\ UNITED STATES ATOMIC ENERGY COMMISSION UNDER CONTRACT AT(45-1)-1830
}




\title{
UNCLASSIFIED
}

BNWL - 518

\author{
SURVEY OF HYDRAULIC MODELING \\ EXPERIENCE FOR REACTOR CORE SYSTEMS
}

by

K. D. Hayden

Equipment Development Section

FFTF Project

August 1967

LEGAL NOTICE

Th1s report was prepared as an account of Government sponaored work Nelther the United States, nor the Commission, nor any person acting on behalf of the Commisslo

A Makes any warranty or representation, expressod or Impilied, with respect to the accuof any information, apparatus, method, or process disclosed in this report, or that the use privately owned rights, or

$B$ Assumea any labilities with respect to the use of, or for damages resultung from the of any information, apparatua, methot, or process disclosed in this report

As used in the above, "person acting on behalf of the Commission" includes any em-

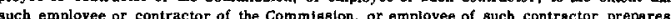
disaeminates, or provides access to, any information pursuant to his employment or contract with the Commission, or his employment with sucb contractor

Approved by

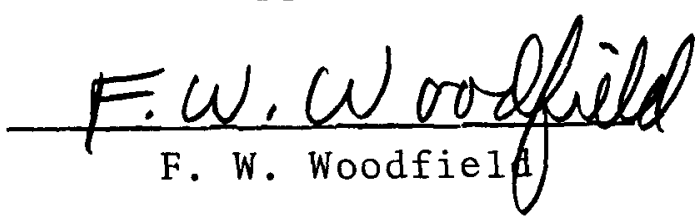

PACIFIC NORTHWEST LABORATORY

RICHLAND, WASHINGTON

UNCLASSIFIED 
INTRODUCTION . . . . . . . . . . . . . . .

SUMMARY . . . . . . . . . . . . . . . .

DISCUSSION . . . . . . . . . . . . . .

Argonne National Laboratory ..............

Atomics International . . . . . . . . . . .

Babcock and Wilcox Company Research Center . . . . .

Battelle Memorial Institute, Columbus Laboratories ...

Franklin Institute Research Laboratories . . . . . .

General Electric Company, APO . . . . . . . . .

Los Alamos Scientific Laboratory . . . . . . . .

Oak Ridge National Laboratory .............

Westinghouse Electric Corporation, APD ..........

41

Visit to PNL by Casimir Pierre Zaleski ......... 
Ore of the more complizated aspects of the Frot. Flux Test Fac1lity (FFrF) design the fluth-flow system timough the reactor core. The proper performance of this system 1s cribleal. As a congequence of the complox rluid-rlow paterns that exist in the reactor, analytical tookm niques for predictiocs of flow rates, pressure dropo, flow distribution, mixing, vibration, mechanicsl fit, deflection and stress to a necessary degree of accuracy are not completely avallable. Thus, model studies of the reactor vessel and core system have become a necessary part of the design development and verification efforts.

Having established the general support reed for FiF, visits were made to varlous sites helleved to have experlence snd competence in reactor desigas, modelirs ard operation to permiz ditilization of the existing testing experience in the Hydraulic Core Mockup (HCM) scopins studies. Visits were made to some nine selected sites(I) to determine 1) specific modeling experience, 2) why were reactor models used or not used, 3) what determined the size and fluld used, 4) what techniques proved most successful, 5) what problems, if any, were encountered in conductirg their choser program, and 6) how well tha data obtalned from model studies compared to the prototjpe data.

\section{SUMMARI AND CONCLUSIONS}

Results of the discussions held at the various survey sites(I) and subsequert correspondence indicate that experimental test programs utilizing models of complete systems or portions thereof are required in the design and construction of complex hydro-mechanical systems and equipment. Only in relatively simple mechanical or hydraulic systens are the analytical techniques sufficiently leveloped to permit design of workable configurations without the use of rodels. Even in simple systems, models are utilized if the consequenes of system failure or deficiency zive s significant impact on the successfdi impiementation of tise destred mission. Mission objectives are a prime corisideration in assessing the degree of accuracy required in analjei.j of syetem performince. The folloving survey in Table I lists the sites, reactors, model slae ard experimental studies conducted for design inport of various reactiors constructed by or for the sites surveyeç.

Model. - has been conlueted at vartuds siales ooth larger and smalle: than the fi. - assemply. Ite need $\mathrm{fr}_{\mathrm{r}}$ incressed scale models exists for those systei where flow paths are smali snd complicated and where da'ta sensors have a signifissnt effect an zyramis conditions. In practice, the use of increesed scele modeis has beer limited to fuel subassemblies and single, flow chanrel-fusl assembilas. Resctor core snd vessel models have been corstructed on a l:2 cw rejured scale bails.

1. See Appendix for Sites, Cortecte ard Dates. 


\begin{tabular}{|c|c|c|c|c|c|c|}
\hline STLE. & REACIOR (Coolant) & TESTING & ON & SCAIE & FLUTD & WHAT STUDIED \\
\hline $\begin{array}{l}\text { ARGONME } \\
\text { NATIONAL LAB }\end{array}$ & $\begin{array}{l}\text { ERR-II (Na) } \\
\text { CP-5 }\left(\mathrm{H}_{2} \mathrm{O}\right) \\
\text { FAREI (Na) }\end{array}$ & $\begin{array}{l}\text { Reactor } \\
\text { Reactor } \\
\text { Reactor }\end{array}$ & $\begin{array}{l}\text { Core } \\
\text { Core } \\
\text { Core }\end{array}$ & $\begin{array}{l}0.6 \\
\text { Ful1 } \\
1 / 8\end{array}$ & $\begin{array}{l}\text { Water } \\
\text { Water } \\
\text { Water }\end{array}$ & $\begin{array}{l}\text { Flow Distrikution, } \triangle P \text {, } \\
\text { Flow Paths, Design Confirmation } \\
\triangle P \text {, Control Rods } \\
\text { Flow Distribution }\end{array}$ \\
\hline $\begin{array}{l}\text { ATOMICS } \\
\text { INIEELIIIIONAI }\end{array}$ & $\begin{array}{l}\text { PIQUA (Orgais) } \\
\text { SNAP-BDS (NaK) }\end{array}$ & $\begin{array}{l}\text { Reactor } \\
\text { Reactor }\end{array}$ & $\begin{array}{l}\text { Core } \\
\text { Core }\end{array}$ & $\begin{array}{l}\text { Ful1 } 1 / 4 \text { Sector } \\
\text { Full }\end{array}$ & $\begin{array}{l}\text { Water } \\
\text { Water }\end{array}$ & $\begin{array}{l}\text { Flow Distribution in Moderator } \\
\text { Flow Distribution }\end{array}$ \\
\hline $\begin{array}{l}\text { BABCOCK \&: } \\
\text { WIISOX }\end{array}$ & $\begin{array}{l}\text { KFOWEE DAM PWR }\left(\mathrm{H}_{2} \mathrm{O}\right) \\
\mathrm{N} . \mathrm{S} . \text { SAVAINAH } \\
\left(\mathrm{H}_{2} \mathrm{O}\right) \\
\text { CONSOLIDATED } \\
\text { EDISON }\left(\mathrm{H}_{2} \mathrm{O}\right)\end{array}$ & $\begin{array}{l}\text { Reactor } \\
\text { Reactor } \\
\text { Reactor }\end{array}$ & $\begin{array}{l}\text { Core } \\
\text { Core } \\
\text { Core }\end{array}$ & $\begin{array}{l}1 / 6 \\
1 / 12 \\
1 / 24\end{array}$ & $\begin{array}{l}\text { Water } \\
\text { Water } \\
\text { Water }\end{array}$ & $\begin{array}{l}\text { Mxing, } \triangle P, \text { Distribution } \\
\text { Flow Patterns, Flow Distribution } \\
\triangle \mathrm{P} \text {, Mixing, Residence Time } \\
\text { Flow Distribution, } \triangle P \text {, Mixing, } \\
\text { Internal Configuration }\end{array}$ \\
\hline $\begin{array}{l}\text { BATIETIE- } \\
\text { COLUMBUS }\end{array}$ & $\begin{array}{l}\text { PWR }\left(\mathrm{H}_{2} \mathrm{O}\right) \\
\text { PWR }\left(\mathrm{H}_{2} \mathrm{O}\right) \\
\left.\text { PWR ( } \mathrm{H}_{2} \mathrm{O}\right) \\
\text { PEGCFR (He) } \\
\left.\text { PWR ( } \mathrm{H}_{2} \mathrm{O}\right)\end{array}$ & $\begin{array}{l}\text { Lower P } \\
\text { Therial } \\
\text { Reactor } \\
\text { Reactor } \\
\text { Reactor }\end{array}$ & $\begin{array}{l}\text { lenum } \\
\text { Shield } \\
\text { Core } \\
\text { Core } \\
\text { Core } 2\end{array}$ & $\begin{array}{l}1 / 4 \\
1 / 4 \\
1 / 4 \\
1 / 4 \\
0.4\end{array}$ & $\begin{array}{l}\text { Air } \\
\text { Air } \\
\text { Air } \\
\text { Air }\end{array}$ & $\begin{array}{l}\text { Mixing } \\
\text { Flow Restrictors } \\
\text { Flow Distribution } \\
\text { Flow Patterns, Mixing \& } \Delta P \\
\text { Flow Dist. . Mixins \& AP }\end{array}$ \\
\hline $\begin{array}{l}\text { FRAIKITN } \\
\text { MISTMUIT }\end{array}$ & EBR-II (Na) & Reactor & Core & .0 .6 & Water & Flow Distribution, $\Delta P$ \\
\hline $\begin{array}{l}\text { GETVTAT, } \\
\text { ETECIRTC }\end{array}$ & $\begin{array}{l}\text { SEFOR ( } \mathrm{Na}) \\
\text { SEFOR }(\mathrm{Na})\end{array}$ & $\begin{array}{l}\text { Reactor } \\
\text { Outlet }\end{array}$ & $\begin{array}{l}\text { Core } \\
\text { Plenum }\end{array}$ & $\begin{array}{l}1 / 2 \\
1 / 2\end{array}$ & $\begin{array}{l}\text { Wator } \\
\text { Water }\end{array}$ & $\begin{array}{l}\triangle P \text {, Distribution, Vibrution } \\
\text { Surface Wave, Gas Ensuimant }\end{array}$ \\
\hline LOS AINMOS & FRCIF & (PROGRA) & M CAITCE & ED PRIOR TO CORF & TESIING) & \\
\hline OAK RIDGE & $\begin{array}{l}\text { HFIR }\left(\mathrm{H}_{2} \mathrm{O}\right) \\
\text { MPRE }(\mathrm{K}) \\
\text { MRJ' }\left(\mathrm{D}_{2} \mathrm{O}\right) \\
\operatorname{MSRE}\left(\mathrm{UL}_{4}\right) \\
\operatorname{MSRE}\left(\mathrm{UF}_{4}\right)\end{array}$ & $\begin{array}{l}\text { Reactor } \\
\text { Reactor } \\
\text { Reactor } \\
\text { Reactor } \\
\text { Reactor }\end{array}$ & $\begin{array}{l}\text { Core } \\
\text { System } \\
\text { Vessel } \\
\text { Core } \\
\text { Core }\end{array}$ & $\begin{array}{l}\text { Full } \\
\text { Furl } 1 / 2 \text { Sector } \\
\text { Full } \\
\text { Full } \\
1 / 5\end{array}$ & $\begin{array}{l}\text { Water } \\
\text { Water } \\
\text { Water } \\
\text { Water } \\
\text { Water }\end{array}$ & $\begin{array}{l}\text { Flow Distribution, Control Rods } \\
\text { System Operating Cycle } \\
\text { Residence Time, Mxing, Distribution } \\
\text { Dist., } \Delta \mathrm{P} \text {, Mixing, Remote Mintenance } \\
\text { Inlet Orifices, Anti-Sw1rl Vanes }\end{array}$ \\
\hline $\begin{array}{l}\text { WESTINCHOUSE } \\
\text { APD }\end{array}$ & $\begin{array}{l}\text { YAIMEE }\left(\mathrm{H}_{2} \mathrm{O}\right) \\
\text { IND. POIIT-2 }\left(\mathrm{H}_{2} \mathrm{O}\right)\end{array}$ & $\begin{array}{l}\text { Reactor } \\
\text { Reactor }\end{array}$ & $\begin{array}{l}\text { Core } \\
\text { Core }\end{array}$ & $\begin{array}{l}1 / 12 \\
1 / 7\end{array}$ & $\begin{array}{l}\text { Water } \\
\text { Water }\end{array}$ & $\begin{array}{l}\text { Flow Dist., } \triangle P \text { \& Mixing } \\
\text { Flow Dist., } \triangle P \text { \& Mxing }\end{array}$ \\
\hline
\end{tabular}


BNWL -518

$-3-$

The best technical basis for modeling for direct application and therefor accuracy of results is a $1: 1$ scale utilizing the identical fluid intended for use in the modeled facility. For large systems the high cost of 1:I scaling is not justified by the incremental gain in data accuracy for hydraulic parameters. Judicious use of the established scaling laws permit the use of scaled down models for hydraulic studies. For facilities where the mechanical arrangements are complex, fluid velocity is high, flow paths are numerous and where temperature profiles are significant, data extrapolation from models of greatiy reduced scale cannot be accomplished with a high degree of confidence.

The choice of working fluid in most of the modeling studies has been water. Air has been used by Battelle Memorial Institute (Columbus) with good success as has $\mathrm{CO}_{2}$ by Franklin Institute. The types of reactor prototype coolants that have been modeled with water as the working fluid include sodium, potassium, organic, molten salt, heavy water and light water. The dynamic properties of water were close enough or could be adjusted to those in the prototypes so that extrapolations were minimized. In some cases of sodium reactors, water was preferred over use of sodium because more accurate data could be obtained through use of standard instrumentation and experimental techniques.

Use of water, air and $\mathrm{CO}_{2}$ for test fluids has permitted standard instrumentation to be used for pressures, pressure drops, temperature and flow rates in the models. Specific determinations such as flow distribution, flow paths and mixing have been performed by many techniques. With both water and in systems, visual techniques have been used to determine flow paths. Colored streams or beads have been used with water and smoke has been used with air. However, conductivity probes with electrolyte injection or thermocouples or thermistors with a different temperature stream injection seem to be used most with water and $\mathrm{CO}_{2}$. Conductivity has an advantage in that it does not disappear downstream for accurate determinations at detection locations. Potential disadvantages are that the technique requires more effort in interpretation of the data and the non-disappearing property of the electrolyte tracer requires once-through operation unless the noise analysis technique* for data analysis is used.

*The basic technique involves amplifying, filtering, recording and analyzing induced or inherent, periodic or random, fluctuations from electronic transducers sensitive to conductivity, temperature, flow rate, etc. Specifically for flow distribution the nolse analysis method involves injecting salt solution into a system at a slow constant rate. Hydraulic turbulence breaks the concentrated salt solution into small eddies which propagate through the system and appear at the detectors as random variations in conductivity. Measurements are made of the transit delay of conductivity variations between two cells along the same coolant channels. Since the cross-correlation function between two random coherent signals has a maximum positive value at a time delay corresponding to the transit delay between the two signals, a crosscorrelation computer can be used to accurately measure the transport time. 
If the flow rate required is high, continuous or once-through operations may be difficult to attain, or the test duration must be very short within the limits of storage capacities, $t$ emperature measurements have the advantage of a disappearing tracer (if heat exchangers or heaters are used) but the disadvantage of frequent calibration, some interpretation of data because of heat loss or gain to the surroundings during the run and, in some cases, short run times. Other instrumentation used in the studies have included heat meters, Pitot tubes, vibration meters, strain gages and velocity probes.

Small scale faclifties are not generally accepted for experimental testing of mechanical and structural parameters. Attempts have been made to obtain mechanical stress data on reduced scale models but the data obtalned has not been reliable and the resulting analysis is usually questionable. Qualitative vibration information has been obtained from several scale model fluid flow tests, but quantitative data, to date, has required full or near full scale models. The scaling down of mechanical fits, tolerances, surface finishes, strength-to-welght ratios and impact ratio becomes a formidable engineering task and the results are questionable in complex systems.

Generally, confirmation of model test data in the prototype is not done because $1 t$ would mean extra instrumentation not necessary for actual reactor operation. Model data stands by itself as being accurate. In a few cases, where prototype data have been applicable to model data, there has been good agreement between the two. The best information on comparison between model and prototype data was at Oak Ridge National Laboratory where full scale models were used. For several of the prototypes tested It was stated that "predictions made from data obtalned from the model were verified in every case in reactor operation".

Model data have been quite close to design predictions ( $5 \%$ in some cases reported) and a very useful purpose is served for design confirmation. One of the best justifications for model testing is that almost without exception some changes in configuration which would be beneficial to the prototype have been found as a result of model testing.

\section{DISCUSSION}

The reactor modeling work performed at each of the sites visited is listed separately and alphabetically in the following section of the report. A rough draft copy of the report dealing with the write-up of the modeling performed by that site was sent to each site for comments and corrections prior to publication. In cases where supplementary information was received from the companies the information has been included. The reviewers at each site included the following:

Atomics International, L. E. Glasgow

Argonne National Laboratory, R. A. Jaross

Babcock and Wilcox, T. M. Campbell, Jr。

Battelle Memorial Institute - Columbus Labs, J. A. Eibling

Franklin Institute Research Iaboratories, J. Pendleton Waggener

General Electric - APO, D. R. Riley

Los Alamos Scientific Laboratory, W. R. Wykoff

Oak Ridge National Iaboratory, I. Spiewak

Westinghouse - APD, A. S. Kitzes 
ARGONNE NATIONAL LABORATORY

EXPERTMENTAL BREEDER REACTOR-II (EBR-II)

(The EBR-II model testing is also included in the Franklin Institute Research Iaboratories section of this report, page 28.)

Why was the reactor model built?

The ERR-II Reactor model was built for design confirmation of the hydraulic characteristics of the core. The 0.6-scale model was built and tested by Franklin Institute Research Laboratories. Besides flow distribution, pressure drop and flowpaths in the core, two design features of the reactor outlet were also a cause for concern. The first of these was that the reactor had a single outlet, which meant there could have been problems with uneven flow through the core if the outlet baffle didn't perform as expected. The second was that about a $60^{\circ}$ sector of the outlet baffle had to be removed for the fuel transfer arm and the effect of this was somewhat uncertain. Visual observation of the radial outward flow paths above the reactor core were deemed to be useful and comforting before reactor operation was started. The EBR-II model was used partially to supply design data and mainly to confirm the design.

What other models were used?

A 2.9X-scale model of a single fuel subassembly was used with water to determine velocity distributions and static pressure differentials within the fuel element bundle. Also, a full-scale bundle of fuel elements, in a transparent tube, was used with water to determine mixing coefficients in the bundle. Dye was injected at the bundle inlet and the dye's dispersion at the bundle outlet was analyzed photometrically.

A full-scale sodium model for a fuel subassembly was used at operating temperature to verify the full-scale water tests, to study structural behavior and to observe effects of flow-induced vibrations, if any, at reactor temperatures. In addition, operation of one control rod was tested in another leg of the same sodium loop. Leakage flows past the lower grid plate were measured.

A 1/4-scale model of the reactor tank was used with sodium, primarily to test the under sodium fuel handling and maintenance. Fuel removal was tested with the plates deliberately bowed, different clearances, etc.

What determined the size of the reactor model?

Originally considered for EBR-II testing was a $1 / 4$ scale complete reactor core model together with a full-size reactor segment of $60-180^{\circ}$. Since the reactor has a single outlet, the segment didn't appear to fit in well for flow behavior and a $1 / 2$ scale model was decided on as the best compromise. Since Franiklin Institute had the flow capacity for a 0.6-scale model, this size was finally chosen to be built and tested. 
What decided choice of fluid used in the reactor model?

Water was used, rather than liquid metal, for testing because of economic, technical and schedule reasons. It was mentioned that extrapolation of hydraulic water data to sodium value gives more accurate data than tests run in sodium as instrument readout is more precise. In performing tests of systems like the reactor core, time is one of the most important factors. Use of water as the model fluid improved the schedule, but still only limited mixing studies were completed even though more detailed mixing data in the vicintty of thermal baffles was considered desirable.

What mixing or data technlques were used in the reactor model?

Flow rates through scale fuel subsssemblies were experimentally established using pressure drop tests to size internal orifices. These internal orifices were used with individual scale subassembly pressure drop curves to give flow values in the scale reactor. Mixing studies were performed by introducing India ink into selected subassemblies to permit visualization of flow in the upper plenum which was fitted with a transparent Iid. High speed motion pictures were taken. Static pressure measurements near subassembly entrances and exits were taken. A pressure drop gradient was determined during the reactor model testing by comparing the flow of scale subassemblies in the scale reactor and their curves determined from the scale test loop simulating the reactor configuration. This gradient was attributed to the interaction of the flows entering the subassemblies due to the close proximity of certain high velocity entrance openings.

How well did the model data work?

The model data was sufficiently accurate that provisions were taken in the reactor to accomodate the pressure drop gradient found in the model testing. It was determined that hydraulically the testing confirmed the design. The model has not been used since the reactor was started since there weren't any serious problems with the reactor that could have been solved with the model.

Overall opinion of Argonne model studies

Hydraulic studies of the EBR-II reactor vessel were important to confirm design, point out fine design features that are not amenable to calculation and for observation of predicted hydraulic flow paths. Since most model hydraulics were about as expected and certain results didn't affect the reactor design appreciably, most studies were classed as design confirmation. The assurance was there, however, after the model studies that the hydraulics of the reactor were as planned and operation wouldn't be detrimentally influenced because of them.

The choice of model size and fluid was adequate for the evaluation, and there were no regrets on either size or fluid used on hindsight. There are many factors affecting choice of models. If it is necessary that the reactor system operate successfully on startup, it is almost mandatory 


$$
-7-
$$

that a model of at least $1 / 2$ scale (for the reactor size of EBR-II and FIR) be used to test reactor hydraulics prior to reactor operation.

\section{FFTF model application}

Several oomments were given about testing for the FFIF. Several of these follow:

- The test setup should be tailored for a specific job and should not be extremely flexible.

- Reactor model scale size should be at least $1 / 2$, and better full scale to study gross fluid behavior.

- The test fluid should be water rather than sodium, and where practical, components should be stainless or brass rather than carbon steel to avoid plugging of small passages and instrument sensors.

- Thermistor method is best for mixing determinations because it takes less interpretation than conductivity.

- Plastic heads should be used for visual flow patterns.

- Segments work well but build a larger section than necessary (where instrumentation is used) to eliminate boundary conditions.

- Test flows with different size orifice holes, clearances, pressures, and positions so any changes later on in the reactor can be predicted.

- Check bypass flows (e.g., between sections of inlet plenum) as a function of hydraulic resistance. Particulate deposition is important there.

- Check holddown of various components.

- Evaluate mixing in upper plenum. Several schemes to promote mixing may have to be evaluated since the fluid residence time is very short.

- Take pressure and differential pressure determinations at many positions, especially where spacings between components are small. This should be done with extreme care for bypass type flows where a small error in differential pressure corresponds to a large error in flow.

- Modeling of natural circulation should be done on full-scale exact replicas of the systems of interest.

- Other models (single purpose mockups) provide essential data and confirmation, and these would probably be necessary for the program. 
Supplementary Material Recejved From Argonne National Laboratory (1)

CP-5 Reactor

The work on CP-5 was performed on a full scale mockup and was concerned mainly with control rod operation and pressure losses through the core. A separate test of approximately $1 / 5$ scale was also made to check the flow baffle design at the reactor inlet.

BORAX AND EBWR

An extensive heat transfer program was carried out which lent confidence to the hydraulic calculations made for the core design of the BORAX series of reactors and EBWR. No specific core model testing was done for these reactors except a small $\left(\sim 5^{\circ}\right)$ full-size core-segment test for EBWR in which the bubble carryover problem was studied. Generally a "boot strap" approach to the hydraulic design of the bolling water reactors was used.

Fast Reactor Test Facility (FAREP)

(The following is a report of FAREI testing on the pressure vessel prior to cancellation of the project).

The one-eighth-scale model of the FARET pressure vessel is an adequate rather than true model of the prototype. A true model is one in which all significant characteristics of the prototype are accurately reproduced. Besides geometric similarity, the model must satisfy all other restrictions introduced to the design conditions. Because of cost or time, a true model may be too elaborate, and an adequate model may be all that is required for analyzing a particular characteristic. An adequate model then is a model from which accurate predictions of one characteristic of the prototype may be made but will not necessarily yield accurate predictions of other characteristics. Other investigators' experiments have shown that the flow distribution can be predicted with an adequate model. With this basis, the one-eighth scale model was built to predict the flow distribution within the FARET pressure vessel.

In the prototype reactor pressure vessel, there are five main flow paths. The reactor core sodium flow is $6,000 \mathrm{gpm}$ and the reactor bypass flow is $1,500 \mathrm{gpm}$. Total flow into the pressure vessel is $7,500 \mathrm{gpm}$. Of the 6,000 gpm flowing through the core, 1,000 gpm flows up past the upper reflector and only 5,000 gpm of the core's 6,000 gpm goes into the exit mixing baffle. Of the 1,500 gpm bypass flow, 15 gpm flows into the auxiliary piping system during normal operation of the reactor and 434 gpm in the event of a major failure in the primary system the rest combines with the 5,000 gpm of the core in the mixing before going to the main exit.

1. Letter, Comments and Review of FFTF Trip Report on Reactor Core Modeling Meeting at ANL on October 26, 1966, L. T. Pedersen from R. A. Jaross, April 20, 1967. 
The model was designed so that the core flow, flow up past the upper reflectors, and the bypass flow could be all separately controlled and measured. This situation does not exist in the prototype, and it is believed that the model should have the flexibility of adjusting the flow rates into the vessel. The flow loop was designed for either recirculating flow or once-through flow operation. The once-through circuit was necessary so that any indicator used for the mixing analysis that is introduced into the model would not be recirculated. However, experiments have been made trying to recirculate and analyze the system. In a very short time (within 3 seconds) the entire loop has indicator throughout the entire system and it is then difficult to remove the indicator material from the system fluid. The once-through system has worked very well. A large vessel holding 320 gallons was used as a reservoir for the system. In some tests, 50 gallons per minute were used. This flow rate meant that about 6 minutes was available to analyze the event before the water supply was exhausted.

The one-eighth scale model was constructed of cast acrylic tubing. A $16 \mathrm{~mm}$ movie (ANL-MP-730-78) was taken which shows water flowing at $13 \mathrm{gpm}$ and $1.3 \mathrm{gpm}$ and a simulated event of a major break in the 24-inch sodium exit system. Movies were taken at 20 and 50 frames per second. At 20 frames per second, each frame gave the position of the dye, 0.05 seconds apart. Dye position and change of position were noted by projectIng the pictures frame by frame. A coordinate system was set up on the screen so a reference system could be established. The pictures were enlarged on the screen 2 to 4 times when there appeared an advantage to do so.

The flow distribution test was intended as a search to look for any discrepancies in the flow between turbulent and laminar regimes. The flow distribution appeared to have the same distribution for high flows and low flows. The other type of test that was conducted simulated the event when the 24-inch diameter sodium exit pipe was ruptured and flow into the pressure vessel was decreased. The movie shows flow reversal of the bypass flow in the event of a major break in the 24-inch exit pipe bypass flow - first going into the mixing chamber and then coming out and then into the auxiliary bypass line. Another movie was made of the one-eighth pressure vessel in normal operating condition. This time, the flow into the vessel was $50 \mathrm{gpm}$. In the first movie, dye was injected in one stream at a time. In this second movie, three dyes were used, black, red and green. The dyes were altered so one-half of the vessel could be arranged to be analyzed at the same instant..

The flow and velocity distribution of the core and bypass circuits as they mix on the way to the exit was determined. The design condition of having the Reynolds numbers in the model and in the prototype equal, was not met. Therefore, the velocities in the model could not be correlated to that in the prototype. However, since there was geometric similarity in the model, the velocities relative to one another in the model were expected to be in the respective proportional ratios when comparable geometric positions were used in model and prototype. Through the use of the model, a more thorough understanding of where and how the flow was being directed was determined. The knowledge gained on this 
model will be applicable to the deslgn of the one-half scale model of the FARET pressure vessel.

A preliminary study of the various fluids was made for a one-halfscale model, and it appears that water is the most favored. Several prime movers were considered for the water pump - steam turbine, gasengine, diesel and electric motor. The steam turbine appears to be the most economic selection, however, because of convention, operation, and maintenance of the machine, a standard electric motor will probably be used to drive the pump. 
BNWL -518

$-11-$

ATOMICS INTERRATIONAL

PIQUA Nuclear Power Facility (PNPF)

Why was the model built?

Subsequent to the Piqua moderator problem, hydraulic testing was done on a quarter-sector, full-scale vessel. The $90^{\circ}$ sector tests were needed to determine the required vessel internal coolant path modifications to provide polymerization product removing action by the coolant in the moderator zone. Primarily the study was concerned with peripheral baffles, downcomers and slotting in them, and how their geometric features promote the circulation of the moderator coolant outside of the fuel channel.

What other models were used?

Prior to Initial operation of Piqua, full-scale water tests were conducted on several model fuel elements to determine hydraulic behavior in the concentric cylinder fuel elements. Pressure drop measurements on a full-scale fuel element were also obtained in Santowax-OM at temperatures up to $800^{\circ} \mathrm{F}$ and prototype flow rates. Air was also used as a model coolant for obtaining sensitivity and traverse capability in Pitot tube flow channel velocity measurements. Water tests were not amenable to Pitot tube use since the smallest needed tube diameter ( $\left.1 / 8^{\prime \prime}\right)$ would have been too large compared to the flow channel dimensions to provide reliable data.

What determined the size of the reactor moderator flow model?

A 1/2-scale model was considered, but it would not have satisfied the modeling law in all respects and so the full size was used. The $90^{\circ}$ sector was selected because it provided two different boundary conditions which exist adjacent to the center channel.

What declded choice of fluid used?

Water was used because kinematic viscosity similitude exists for water and Santowax $\mathrm{R}$ at $125^{\circ} \mathrm{F}$ and for Santowax OM at $175^{\circ} \mathrm{F}$. The use of water allowed existing faclilties to be used to perform the tests quickly and economically. The model core vessel was fabricated from aluminum, plexiglass tubes were used for fuel channels, and each side contained plexiglass windows at inlet, middle, and outlet levels. Other tests on individual fuel elements have employed stainless steel loops.

What mixing or data techniques were used?

After setting up the test baffle and or downcomer arrangement and fixing the moderator flow, neutrally buoyant opaque plastic beads were fed into a selected channel. Movies were taken during the tests at 64 frames/second. Analyses of the velocity and mixing were made by screening the movies. The beads were 5/16-inch diameter polypropylene with a nominal specific gravity of 0.92 . 
In arriving at the above technique, several other methods were considered and included (I) salt injection (which has high cost and low velocity threshold when the salt is diffused), (2) flow streamers, (3) mass transfer, (4) soluble surfaces and (5) thermistors. The bead technique was determined to satisfy the needs best.

How well did the reactor model data work?

By performing model tests on various designs and modifications to baffles and downcomers, a satisfactory arrangement was found which optimized the performance. By use of the movies which were taken, the flow distribution and velocity variables could be determined qualitatively and, in some cases, quantitatively.

Sodium Reactor Experiment (SRE)

Full-scale, single-channel hydraulic tests were conducted to study mixing and determine pressure drops. In addition, 3-1/2 to 1 scale tests of core vessel lower and upper plenums were made for core flow distribution studies. The salt velocity technique was used, with sodium nitrate as electrolyte to determine the flow split in the hollow or annular fuel element design. The technique employed two conductivity cell measurements or the slug method. This technique was the forerunner of the more sophisticated and complex noise analysis technique later employed in the Piqua, SNAP and HWOCR projects.

Hallam Nuclear Power Faclitity (HNPF)

The Hallam support included full-scale, single-channel testing for pressure drop and vibration on the fuel assembly. Strain gauge techniques were employed in the latter tests; although a better approach, now avallable, employs conductivity probes and nolse analysis techniques. No mixing or velocity distribution study was made.

A large effort for Hallam was the computer designed variable orifice calibration study. (In a similar effort in the Piqus program, A-I determined that a standard valve plug design would be suitable to obtain the desired orificing characteristics.) This testing program was critical since all flow calibration as a function of plug position was made in these tests, and this data was applied by means of the Euler number ratio to reactor flow determination. No sodium tests were made at this prestartup stage to evaluate performance in sodium.

Organic Moderated Reactor Experiment (OMRE)

Full-scale-model single-fuel elements were tested in water and air prior to insertion into the reactor. The water tests were primarily directed toward pressure drop measurements; however, salt velocity measurements were used in one case to determine average velocity distribution in the various flow passages. Subsequent Pitot tube velocity measurements using air were in agreement at the Reynolds number for this element. Most of the test elements were given velocity distribution tests in air although the Reynolds number range was limited in the unsophisticated facilities available. 
SNAP Bydraulic Testing

An extensive program was accomplished in which core flows were tailored to match the power profile on the SNAP 1OA, SNAP 2 and SNAP 8 cores. Water testing of full-scale core models and salt velocity techniques $(1)$ were used.

Overall opinion of Atomics International model testing

Atomics International has conducted hydraulic testing (Reynolds similarity) with water (and some air) for all their reactor work. In each case, full scale tests on single fuel elements have been used. Reduced scale model and sections of full scale models have been used to simulate core vessel geometries.

The absence of complete core model testing has primarily been due to lack of economic justification and the judgment that the reactor would perform satisfactorily without such testing.

1. Randall, R. I., Pekrul, P. J., Grayban, G. R. "Development of Nolse Analysis Techniques for Measuring Reactor Coolant Velocities", NAA-SR-I1193, February 1966. 
BABCOCK \& WILCOX RESEARCH CENTER

Keowee Dam PWR - Duke Power Company

Why was the model built?

A 1/6-scale model of the $B$ \& $W$ PWR was built to determine flow distribution, mixing and pressure drop in the reactor system. The model was built of clear pastic to allow observation of all parts of the model. The overall reactor model was designed for exact geometric scaling of linear dimensions, but the core internals were intentionally not geometrically scaled but were scaled to obtain simflitude. One of the factors in the model testing was to match pressure drop ratios or Euler number with the prototype.

What other models were used?

A lOX-scale model of one fuel pin was built to study the flow distribution around the pin spacer and dimple. The model consisted of the pin and spacer, with the dimple against one side of a square transparent plastic flow box. Flow visualization was made possible with upstream dye injection. High speed motion pictures were used to qualltatively analyze the results. Pressure drop tests were also made and compared with results from a full scale partial-pin model. The results of this comparison were in good agreement. The Reynolds number for the IOX flow model was up to 460,000 , which is a match for the prototype.

A four-pin full-scale model of a fuel assembly segment was used for pressure drop and mixing studies in support of the $B$ \& W PWR effort. This model was an exact geometric replica of a four-pin segment of the fuel assembly including pin spacers. Mixing studies were carrled out by injecting a salt brine solution in the center channel and sensing the concentration at various downstream points in the central and neighboring channels. This study will be extended to include an exact geometric replica of the full fuel assembly for the PWR (a $15 \times 15$ array). $B \& W$ also has an active program on flow induced vibration tests in conjunction with the full-fuel assembly mockup.

\section{What determined the size of the model?}

The model size was chosen primarily on an economic basis consistent with obtaining quantitative data. The $1 / 6$ scale represented a 4,000 gpm flow rate through the reactor model. Reynolds number ratio of prototype to model was 36 to 1 . For testing of individual components, including reactor fuel subassemblies and assemblies, full scale or larger models were used. Wherever possible, testing was done hydraulically on components individually and the results of these tests put together analytically to determine system behavior. Tests with models of systems generally are performed only where interactions between components are expected to be significant. 
What declded the choice of fluid used?

Water has always been used in model testing for liquid systems. The reason for this is the blower capacity required to obtain representative prototype Reynolds numbers w1th gases is too high. However, matching Reynolds numbers are not necessary for flow distribution and mixing studies as long as they are in the turbulent region. The other preference for water is that visualization of flow patterns is better with water than gas. In fact, some studies of flow patterns in gas systems have been made using water.

The use of water has required stainless steel piping for the reactor model to prevent corrosion and rust problems.

What mixing or data techniques were used?

Parameters measured in flow tests were flow distribution, fluid mixing, and static pressure drops. Sensing lines lead from vartous points in the model to water manometers for pressure drop measurements. Pressure drops at venturis and orifices were used to measure flows in parallel channels and to determine flow distrlbutions.

Mixing studies were conducted by several methods:

- Water entering from different inlet lines were at different temperatures and thermocouple readings made at different locations in the model.

- A brine solution was injected at certain locations and measurements made with conductivity probes. Pulsed brine injection was used also for velocity studies.

- Various tracers such as dyes and condensed milk were introduced into the water stream for visual studies of flow patterns. Some visual studies were made using small particles of plastic, with a specific gravity of about 1.0 as tracers. At low velocities, time exposure photographs allow paths of such particles to be traced.

Velocities in plenums and other larger chambers were measured with small propeller-type velocity probes.

The flow and temperature data in the reactor model goes directly into a data acquisition system, on to punch tape and then to a computer. By this method the results can be analyzed and mapped in a very short time.

How well did model data work?

No comparative data has been received from a reactor system so the results of the model tests stand by themselves. 
Some correlative flow data for scale models and prototypes of heat exchanger and steam generators show good agreement. Experiments were conducted with two models of a single fuel rod and spacer clip from a $15 \times 15$ rod element using full-scale and 10X-scale models. Pressure drop agreement between the two models was good.

Accurate quantitative vikration information could not be obtained from smaller scale models without an extensive $R$ \& $D$ program to develop modeling techniques. In fluid flow models, qualitative studies of oscillatory fluid force patterns were made to see if these forces might be great enough to be of concerm. The approach used is, if the forces appear to be high, attempt to reduce them by design changes rather than conducting more rigorous viluration tests.

Overall opintion of Babcock and Wilcox model work

$B$ \& $W$ prefers water to gas for model testing of liquid systems. Flow visualization studies have been made with both gas and water and water was preferred. Whenever possible, hydraulic testing was done on full-scale components individually and the results put together analytically to determine system behavior. In something as complex as flow through a reactor, where it was necessary to establish flow distribution, mixing and pressure drop, complete model was required because of the interaction between components. The choice of complete system scale size was primarily dictated by economics consistent with obtaining accurate data.

In most cases model studies were the best method of optimizing parts of systems or pieces of equipment such as a heat exchanger or steam generator. Changes can be made readily to try different designs and operating parameters. Reactor model studies were required both to assure the system performed as intended and to provide data to make corrective changes as required in the design to insure adequate performance of the prototype.

\section{FFTF model application}

Based on individual comments, it is concluded that hydraulic (water) core testing would be necessary for the FTR, although the specific scale of the model could sot be suggested. other models (single purpose mockups) provide essential data and confirmation, and these would probably be necessary for the program. 
SUPPIEMENTARY MATERIAI RECEIVED FROM THE BABCOCK AND WILCOX COMPANY, RESEARCH CENTER (I)

Water Model Tests of N. S. Savannah Reactor

Flow model tests of the reactor for the N. S. Savannah were conducted to provide information on flow patterns, flow distribution, pressure drop, mixing, and residence time. This information was required to confirm design calculations and to provide a basis for determining safe power levels for the reactor. As a consequence of not running these tests, a more conservative estimate of reactor output would have been required, with final confirmation being established during operation. This approach could have led to undersizing some components in comparison to the reactor capacity.

Available analytical methods and computer technology cannot provide complete data on such items as flow patterns and flow distribution, requiring that these data, or at least some of the analytical input, be obtained from a physical model study. Pressure drop and mixing normally can be calculated for many configurations with reasonable accuracy and, in these cases, the model serves primarily to establish a high confidence level for the calculations. Average residence times can be readily calculated, but the presence and effects of local hold-up zones or areas of recirculation must be established from model tests.

In terms of complexity, the flow system used in these tests was simple. Water at low pressure and low temperature flowed through the plastic model and then to the drain, with flow being monitored at each inlet and outlet of the model. The reactor model, however, had all the essential complexity of the full scale reactor. This reactor is a three-pass design in which the coolant enters the bottom, flows up through the thermal shield area, down through the first pass of fuel elements, and up through the final pass of fuel elements, leaving at the top of the reactor vessel. In the model all areas were geometrically scaled except for the fuel elements. Each fuel element was simulated by an assembly containing a flow metering section. The simulated elements were designed to match the Euler number for the prototype condition.

Each simulated fuel element was calibrated in a separate small flow loop prior to installation in the reactor model.

The model simulated the entire reactor vessel and the core. It was designed only to provide data for the N. S. Savannah configuration and was not versatile in terms of general usage. It did provide a good degree of flexibility for the use of various experimental techniques to obtain the required data.

Selection of $1 / 12$ scale for the model was based mainly on convenience for fabrication and use. Factors such as water circulating capacity and cost were also considered in making this selection. One-twelfth was considered the smallest scale that could be used with a reasonable degree of confidence in the results. Manufacturing tolerances on flow areas were held within $1 / 2 \%$. 
This model was the flrst in a serles of reactor models. Its use, however, was based on many years of experfence in the use of water models for the solution of flow problems in heat exchangers and boller components. The model size was adequate for the intended use but a larger scale would have been more convenient from the standpoint of making machining tolerances less critical. Also, our facillties have been expanded considerably since the Savannah model tests were run. Should this model be re-constructed today we would probably choose a scale of $1 / 6$ or larger.

The size of the model did not cause appreciable instrumentation problems, and approximately the same instrumentation would be used today. It consisted primarily of venturi meters in the simulated fuel assemblies to measure flow distribution, and static pressure taps at numerous locations to measure component and overall pressure drop. Conductivity cells were used in the inlet and outlet nozzles to measure residence time in the model during operation with electrolyte addition.

Reynolds number in all critical spaces in the model were well above 10,000. Based on our experience and that of other investigators, exact Reynolds number similarity is not essential to investigation of dynamic behavior, so long as both the model and prototype are operating in the turbulent region. This is usually defined as being at Reynolds numbers above 10,000 .

In addition to providing data on the items previously mentioned, the model was used for 1llustration of the components in the reactor and for training sessions for crews and operators.

Changes of a drastic nature could not be readily made on this model. The core, for example, was a completely soldered brass assembly and changes in this area would have been very costly. Fortunately, none were necessary. The external shell, however, was constructed for ease of disassembly and changes in these components could be made with little difficulty. The changes actualiy made during the tests consisted only of adding pressure taps and connections for dye injection into various locations. When designing these models the areas that may require extensive investigation, and will be subject to change, can usually be defined. Normally, it is then possible to design the model to facilitate these changes.

Choice of water for the working fluid in the model was based on several factors. Of primary consideration was the desirability of attaining the highest possible Reynolds number while keeping the model size small and the cost relatively low. In addition, we have used water models for many years for the study of both Iiquid and gas flows. This experience over the years has demonstrated that models using water as a working fluid are more convenient for use in our laboratory. System availability was not a factor since both air and water supply systems were installed in the laboratory.

Since the reactor coolant is water, the use of water in the model simplified extrapolation to reactor conditions. Had air been used the density variations would have been significant, requiring that compressibility be considered. This would have injected another factor into the extrapolation and is a complication we avold whenever possible. 
Data accuracy is generally better using a water model. One basic reason for this is the ability to use weight tank methods for precise calibration of flow meters.

Another important reason for using water is the ease with which tracer techniques can be applied for flow visualization. In this model, dye and air bubbles were used as tracers. In some cases, we use solid particle tracers where the particles have a specific gravity of 1.0 . In the reactor model, however, the small passages in some areas precluded the use of particulate tracers.

Were we to do this job today it is certain that we would again use water, and the same tracer materials. In fact tests of this nature are currently in progress, providing data for the present and future generations of large utility reactors.

As a general practice, non-corrosive materials were and are used in the flow loops. Plastics, brass, copper, and aluminum are widely used because of the ease with which they can be joined or fabricated. Stainless steel is used extensively for loop piping.

The model is operated Isothermally at low temperature with thermal effects being handled strictly by analytical methods in applying the model data to the prototype. Since the fluids in both the model and the prototype were essentially incompressible, pressure simulation was not a problem.

To measure mixing in the model we used electrical conductivity measurement with sodium chloride brine as a tracer. In addition, qualitative mixing estimates were made by visual techniques using dye tracer.

Pressure taps were of normal drilled and de-burred construction. Pressure tubes from the venturi meters in the fuel assemblies and other Internal locations were led out through the simulated control rod guide tubes in a manner that would not cause interference with the normal flow paths in the model.

Inlet flow to the model was measured by standard orifice meters in each inlet line. Outlet flows, however, were measured by means of elbow meters on each outlet.

Accuracy of model data is in many cases difficult to confirm, due to lack of feedback information from the prototype. In most cases the prototype is not instrumented to provide the information required to make detailed comparisons. If trouble develops then an attempt may be made to compare with the model results. In this case, such trouble did not develop.

No significant changes were made in the reactor design as a result of the model tests. They served primarily to confirm calculations and provide additional input data for performance prediction. 
If we were to repeat the same job today we would use essentially the same techniques with some refinement in the area of data logging. Because of improved flow handling capability, we would probably use a larger model scale.

Since B \& $W$ does a complete job on a system such as this, including design, construction, and testing, it is very advantageous that the same company do the modeling and the data analysis from the standpoint of maintaining a closely integrated effort from start to finish of the job.

Interpretation of the data from the model fluid to the reactor flutd was relatively straightforward and did not present any problem. This consideration was one of the factors influencing the initial cholce of water as the working fluid for the model.

The model data was worth the cost because it (I) provided assurance that there were no unforeseen flow problems in the reactor design and (2) provided a sound basis for calculations to specify power levels and pumping requirements for the plant.

Our overall oplnion is that model studies are well worthwhile: In many cases they present the only reasonable means for obtaining data required to predict performance and to optimize hydraulic design character1stics. In many cases models have exposed unexpected areas of potential trouble, allowing design modiflcations to be made prior to final design comitment on the reactor. That this opinion 18 widely shared is evidenced by the Increasing use of models by our company and others as new designs are concelved.

The quality of the data from model studies has steadily improved due to use of larger scales, refinement of techniques, and improvement of instrumentation systems. Air or water are normally first choices as working fluids for models because of their availability and the ease with which they can be handled. We would not use hazarouds fluids or fluid conditions unless it were essential to similitude. To date, water has been used for all of our reactor models.

With regard to model requirements for FFTF, we believe that some of the hydraulic data pertaining to the core, such as flow distribution and mixing would have to come from model studies. In terms of relative ease with which data can be obtained, and suitability from a similarity standpoint, water at comparatively low temperature would be an ideal working fluid. Generally speaking, the model scale should be as large as possible, consistent with the facilities available, to minimize fabrication and simulation problems and to reduce the degree of extrapolation required. As to whether more than one model would be required we cannot specifically answer this question. However, in many cases relatively simple component models can be used separately to study flow in particular areas in more detail than is practical in a full reactor model. This depends on the particular geometry involved, interaction effects, and the nature of the problem. 
BNWL - 518

$-21-$

This model was used strictly to obtain hydraulic data with all stress and vibration problems handled by analytical means.

The core section in the model was hydraulically modeled but not geometrically scaled. This was due to the small size of the model and the fact that detailed modeling of the fuel assemblies was not necessary to examine the reactor flow characteristics of interest. When detailed data are required for the fuel assemblies separate models using partial or full bundle cross sections of full-sized fuel pins are normally used.

WATER MODEL TESTS OF CONSOLIDATED EDISON COMPANY REACTOR

Model tests of the Consolidated Edison reactor were conducted at about the same point in time as those for the N. S. Savannah reactor, namely during 1958. In general, the reasons for the tests were the same except that the Consolidated Edison model was used more extensively to study various arrangements of internals to develop the optimum configuration. Had the model not been built, the internal configuration would have been based strictly on analytical techniques and judgment. Based on the results of the model tests this approach would have produced a less satisfactory design. This is due to the fact that many flow characteristics cannot be predicted from theory and are configuration dependent to such a degree that the data can only be obtained from a physical model.

As in the case of the Savannah model, the system used for this model was very simple, involving a low temperature, low pressure water supply. The entire reactor was geometrically modeled except in the core and thermal shield areas. As in the case of the N. S. Savannah, the fuel assemblies were hydraulically but not geometrically simulated. Three parallel flow paths in the thermal shield area were combined into one flow path in the model, due to their small size.

This model was more versatile than the Savannah model to permit greater flexibility in changing internals. It was also designed so that sections and sub-assemblies could be tested separately in the development of the most satisfactory internals arrangements. For example, the core and lowerhead assembly were tested as a unit to select internals for the lower head that resulted in the desired core flow distribution. After development of final internals arrangements, the model was completely assembled for the final series of tests.

The Consolidated Edison model was $1 / 24$ scale, the size being based on the same factors that influenced scale selection for the Savannah model. The model size was adequate, however, there is no doubt that a larger scale would have simplified some of the construction and instrumentation problems.

Reynolds number in this model was above 10,000 in all flow passages except the thermal shield zone. However, this was not considered a problem area, and the effect of low Reynolds number in this area was not significant with respect to the remaining portions of the reactor. 
Testing was the primary function of the model, in addition to which it served incidentally for purposes of demonstration and 1llustration.

This model was constructed to facilitate changes in certain areas where developmental modifications were anticlpated. One example is the lower distributor baffle where several different arrangements were tested. 
BATIELIE MEMORIAL INSTIMUTE, Columbus Laboratories, Columbus Ohio Shippingport Pressurized Water Reactor (PWR) (Core 1)

Why was the model built?

A 1/4-scale vessel model of the Snippingport reactor was built to determine:

1. Core flow distribution (plenum factors)

2. Parasitic pressure losses

3. Mixing in the plenum below the core

4. Flow velocities and directions in the thermal shield passages

5. Flow velocities and directions in the plenum space above the core

for operation with four loops, three loops, two opposed loops and two adjacent loops.

The model, was geometrically similar to the reactor except for the core wich was simulated with orificed tubes having the appropriate flow resistance. The model was designed by the Bettis Laboratory, operated by Westinghouse Electric Corporation, and was constructed by the Aviation Gas Turbine Division of Westinghouse. The Battelle-Columbus Laboratories conducted the flow studies.

A separate 1.5-scale model of a portion of the themal shield passages was used to obtain data for the design of the rlow restrictions between thermal shield passages. Data obtained from tine two models were used as a basis for selecting sizes of thermal shield restricting orifices and siort tubes for the prototype and for design of the flow baffle to provide the correct flow through the shield passages.

Following Core 1 studies, the 1/4-scale model was used to obtain data for design of Cors 2. Tho study programs were carried out. In the first study, the effect of the flow baffle on core flow distribution was determined for full and reduced core flow resistance. In the second study, hardware which improved mixing in the lower pienum vas developed for a 7.5-ft and a 9-ft core design.

A full-scale modei of a blanket fuel cluster was used to determine flow patterns arouna burale support grids. Individual rods vere coated with an oil-and-iempblack mixture. Flow patterns were determined by evaluation of the remaining oll mixture after pessing air tinrougin the bundle.

Shippingport Pressurized Weter Raactox (PWR) (Core 2)

Why vas the model built?

A $0.4-s c i c e$ vessel flow model was built and used to obtain design data for the P.R Core 2 progran. Three model configurations were used. Experirental studies of core rlow distribution, mixing of flow from the inlets, mixing of fiow in the space between the lirst and second passes of the bianiet, au prescire crops trrouginout the model were carried out in the orifincl configuration for three-loop and four-loop operation. After modificauions to the flow baffle and the core support barrel were made, the mixing, core flow distribution, and pressure loss studies were repeated. 


$$
-24-
$$

Flow resistances and flow distribution among reglons in the core were then changed and experimental studies of core-fiow distribution, mixing of flow from the inlets, mixing of flow betwcen blanket passes and pressure losses were repeated with four, three, two opposed and two adjacent loops operating."

The design and assembly of the model and the flow studies were carried out at BCL.

What other models were built?

Approximately 3.5-scale flow models were used to determine the nagnitude of channel-to-channel flow maldistribution within the PWR Core 2 seed and blanket fuel assemblies which occurred as a result of the geometric transition from a circular to a square cross section upstream of the coolant-channel inlets. Each model consisted of a plated fuel section and an inlet transition including internal components. Flow maldistribution was determined for four levels of fuel-channel resistance ranging from 10 to 100 percent of reactor fuel pressure loss. Flow maldistribution in the blanket fuel channels was also determined for various flow-control-orifice settings.

Partially Enriched Gas-Cooled Power Reactor (PECCPR)

Why was the model built?

A $1 / 4$ scale vessel flow model was built to obtain design data for the FEGCPR program. The model was used to provide data for design of the coresupport cylinder to provide optimum mixing and core-flow distribution. Following this, experimental studies of core-flow distribution, mixing of flow from the two inlets, flow patterns in plenum spaces, flow patterns in the thermal-shield-coolant passage, and pressure drops throughout the model were carried out. The design and assembly of the model and the flow studies were carrled out at BCL. 
Central Station PIR (Conmercial)

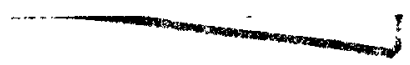

\section{Why is moded being built?}

A 1/5-scale vessel model is being designed by BCL and will be used to determine plenum factors, mixing upstream and downstream of the core, parasitic pressure losses, flow velocities and directions in thermal sinield passages, flow patterns in plenums, and fluid forces on control rod guides. The model will be geometrically similar to the reactor except for the core where orificed tubes having appropriate resistance will be used. The closed-tube core will be modified to simulate an open lattice core following determination of plenum factors. Model piping will be designed to permit modeling of reverse flow in non-operating inlets and outlets.

What determined the size of the models?

In general, the scale sizes vere determined from several bases such as loop capacity, required tolerances for small gaps, economics, reasonable sizes of flow passages and instrumentation. Any convenient scale could be used with no affect on accuracy of results provided one can maintain accuracy in data acquisition, scaled dimensions and tolerances. The scales chosen did allow the Reynolds number to be in the turbulent region with the existing pumping capacity, and changes to the core configuration could be made easily with the sizes chosen. In all cases, the chosen model size was adequate for the information required.

Wrat decided choice of fluid used in models?

In all the modeling studies, air was used as the test f'luid. Air allows a low pressure system, quick alteration of the systern, is econoric, yields reliable results, and simple tracer techniques can be used. Reynolds numbers used are generally high (in the turbulent region) but well below prototype operating values (about $1 / 60$ for the water reactors). Reynolds numbers are not especially important as long as flow is turbulent in both the model and prototype. For cases where most pressure losses are due to momentum changes, or to friction with very rough surfaces, the pressure losses will be alnost independent of Reynolds number for values above 10,000.

Another distinct advantage with air as the modeling fluid is that waterials of construction are no problem. Almost any material can be used with no corrosion problem. Plastic parts for visual observation can be readily used because of tine low pressures used in the systems.

What mixing or data techniques were used?

Flow rates are measured by pressure arons across orifices and vertiries. Pressures are measured at o ain or or locarions in tile model, 
BNWL -518

$-26-$

using vater manometers.

Smoke tracer teckriques are used to study flow patterns. The smoke paths are observed through windcws built into ceriain locations of interest. These studies are conducted initially at low flow velocities to minimize turbulence axd dispersion of the more. The flow patterns are then veriried at a fuld model flow rate. hithough the microscopic flow patterns aro alfferent for hish and low velocity cases, the crosa, or general, flow patterne are independent of velocity. Studies of this type are felt to be valuable for visualizing flow behavior in the system and locating potential problem areas for further study.

Fluid mixing studies are made by injecting sulfur dioxide gas (10 ppm max.) into the air stream of interest and witharawing samples for analysis at downstream points. Tracer gas concentrations are determined immediately in a continuous analyzer. Samples generally are tapped through the pressure sensing lines.

Yaw probes and hot wire anemometers are used to determine local flow velocities directions in plenum chambers and annular flow passages.

How well did model data work?

In general, BCI does not have backup dats for verification of the modeling work other than that, when put in operation, the reactors operated satisfactoriIy. In one instance of the PWR Core 1 model data, it was heard that the data compared within $3 \%$ with data from the instrumented reactor; $3 \%$ being the limit of accumacy of reactor instrumentation. However, the reactor was not instrumented as fully as the model and exactly what data was compared was not known. Another instance that was given was that similar tests were run with a 1.5 scale model using air and a 0.5 scale model with water. Air gave as good data as the water and in flow pattern determinations, the air data was much better than water.

Satisfied customers seem to be the indication of suceess in most cases for modeling work. Air is believed to be ore of the best modeling fluids for the type of work done.

Vibration studies would be difflcult to do with air because of the lack of representative flizid mometum. Vibration studies should be done with a fluid whose properties are tyricsl of those of the fluid to be used in the prototype. Visual flow patterns with air and smoke tracers in small scale models with air might pixpoint sreas of pressure fluctuation and potential vibration. Ilis:s would help direct further studies with full scale models and liquid fuels.

Overall opinion of Battelle-Columivus model studies

Air was considered to be an entirely aatisfactory fluid for use in flow models. Air has the advantage cf being economicsl and simple to use. Noreover with air modifications can be made easily, the properties of air are well known, tracer techriques are easily applied and loop material

presents no problem. Sizes of the models tested didn't appear to be at all 


$$
-27-
$$

critical and were chosen mainly to fit into the existing air supply capacity and to provide reasonable flow passages. The model size can't be too small, however, because eventually it will cost more than a larger model when attempting to accurately duplicate surface locations and eliminating instrument tap interferences. Accurate applicable data can be obtained from any size model as long as the accuracy of data acquisition and scaled dimensions are maintained. Model orlentation, either horizontal or vertical, will not affect the results. With a gaseous fluid, elevation head is negliglble as compared with pressure differences due to friction and momentum changes.

FFTF model application

The free surface of the Fast Test Reactor could probably be duplicated by providing a plate, and air studies could be used successfully for determining the FIR flow distributions, mixing and pressure drops. The fact that sodium will be used in the prototype presents no particular problem and the data would be applicable. 
BNWL - 518

$-28-$

FRAIKLIIN INSTIIUITE RESEARCH IABORATORIES

Experimental Breeder Reactor II (EBR-II)

Why was the model bullt?

The core section model of the EBR-II reactor was built and tested to confirm the flow rates predicted through various zones of the reactor. The studies on the model also included determining the effect of pump fallure and visualizing the flow in the upper plenum. The flow distribution required in the reactor is established by proper selection of entrance hole sizes. The close spacing and subassembly entrance configurations made the effective pressure drop across a subassembly in the reactor vary from row to row and confirmation of flow rates was performed in the model.

What other models were used?

Two calibration loops were set up to be used in conjunction with the EBR-II core model. The first loop was used for callbrating Individual prototype subassemblies in terms of pressure drop versus flow. The second loop was used for calibrating flow through model components, not necessarliy the same size as the prototype components.

What determined the model size?

The EBR-II model was built 0.6 scale, mainly chosen by a series of compromises. Factors considered in selecting size were fluid circulation capacity, cost of model, problems in scaling down small gaps, and necessity of producing adequately high Reynolds numbers without excessive pressure drop. The 0.6 scale finaliy chosen was selected because it corresponded to the maximum pumping capacity available at Franklin Institute. Apart from minor details, the model was an exact geometrical model, with the principal exceptions that the internal flow resistances of the subassembly were simulated by orifices.

What decided choice of fluid used in the model?

Water was used as a working fluid for the EBRR-II, rather than a gas such as $\mathrm{CO}_{2}$ which would have been preferred. For the EBR-II, where a free surface had to be considered, it was difficult, if not impossible, to model with other than a liquid model fluid. Water was used because of its known properties, availability, handling convenience and economy. A disadvantage was the corrosion effect on steel, the most economical material that could have been used for the loop hardware. Stainless steel fabrication costs were prohibitively high and brass fabrication, while expensive, was not used due to extended delivery dates. All the steel pipe was galvanized, the interior of the model reactor was plastic coated, and rust inhibitor was used in the loop water. Even with these precautions, it was necessary to disassemble calibrated subassemblies, clean them, recalibrate and reassemble them into the reactor model. Considerable effort was expended in the cleaning and recalibrating steps. 
BNWL -518

$-29-$

Differences in ideal model using water deviated in two aspects (besides the geometrical difference for the fuel subassemblies). First the temperature, and hence the viscosity and density, was constant throughout the model whereas it is a function of position in the prototype; and second the maximum Reynolds number achieved in the model was one-fourth that in the prototype at full flow. These deviations were taken into account satisfactorily when analyzing the data.

What mixing or data techniques were used?

Flow rates through fuel subassemblies were measured by pressure drop across calibrated orifices. Mixing studies were performed by introducing India ink into selected subassemblies to permit visualization of flow in the upper plenum, which was fitted with a transparent lid. High speed motion pictures were taken of the flow patterns. Static pressure measurements near the subassembly entrances and exits were taken to verify the pressure drop deficit which was noted during the model testing. This deficit was attributed to the interaction of the flows entering the subassemblies due to their close proximity.

How well did model data work?

Information was not available on how well the predictions based on model behavior have matched actual prototype behavior. No experiments have been conducted with similar models or different scales to check on the valiaity of scaling down. It is believed that the scaling laws are fundamental and that results from two models of different scale size would agree. If the model is too small, additional effects which are normally negligible, such as capillary tension and instrunentation interference, may be introduced. There was no great jroblem in interpreting water data obtained in the model to sodium performance in the prototype.

Overall opinion of Franklin Institute model studies

Franklin Institute personnel exhibited a high degree of confidence in the results obtained from their modeling work (although no baclsup data for their tests from prototype reactors was available to therl ). With no time or cost restrictions they would prefer to use full-scale models vith the actual reactor fluid. H.wever, they expressed complete confidence in scaling laws, and believe that accurate flow distribution, pressure drop and mixing data could be obtained from smaller scale nodels.

They prefer a gas, such as $\mathrm{CO}_{2}$, as a working fluid over water because of reduced corrosion and fouling problems. They prefer $\mathrm{CO}_{2}$ to air primarily because of the nigher kinematic viscosity and also because they can obtain high pressure and density in their systom easily by evaporating dry ice. Pressurized $\mathrm{CO}_{2}$ gas has been used over the past ten years 
as the modeling fluid for a series of reactor flow model studies. (1-4) The $\mathrm{CO}_{2}$ test facility has been utilized to determine flow distribution, pressure drop, mixing, transport time in the reactor housing and for the location of failed fuel elements.

They felt the best flow mixing is studied by introducing gas streams at different temperatures and measuring temperatures with small thermistors which are calibrated in place. Mixing measurement is claimed to be accurate within a few percent. Thermal stream tracing is especially convenient since it is a disappearing tracer.

The Franklin Institute personnel felt that significant quantitative mechanical vibration phenomena could be studied in a model provided certain conditions were met. The ratio of fluid density to structural density should be the same in the prototype. Fuel assembly weight would have to be simulated, and $10 \mathrm{~g}$ decrement should be the same as for the prototype.

\section{FFIF model application}

For the FFIF design current at the time of the visit, where the free sodium surface is not intimately connected with the reactor tubeoutlets, they felt that gaseous fluids could be used for flow distribution, pressure drop and mixing studies. (Our impression was that given the FIR Hydraulic Core to model, the scale would be chosen such that a full model would fit into the existing loop equipment.)

The complexity of the Fast Test Reactor would make it necessary to model the reactor system to determine flow distribution and mixing. Spacings between reactor tubes in the inlet plenum are such that there may be interactions which will affect flow distributions and which cannot be calculated. Mixing in the outlet plenum must be investigated experimentally. Flow in this plenum would be so highly turbulent that molecular diffusion would far overshadow thermal diffusion effects. Consequently, only fluid mixing need be studied to determine temperature mixing. Modeling of the entire core, rather than a section, would probably be required to maintain correct flow patterns.

1. D. E. Nestler and J. P. Waggener, "Flow Studies of the AlW Reactor Core Using High Pressure Carbon Dioxide Gas as the Test Fluid", Franklin Institute Report F-Al923, August 1959.

2. J. P. Waggener and H. Balukjian, "Flow Studies of the A2W Reactor Core Using High Pressure Carbon Dioxide Gas as the Test Fluld", Franklin Institute Report F-Al923-2, August 1962.

3. J. P. Waggener and W. F. Touchton, "Flow Studies of the AlW-3 Reactor Core Using High Pressure Carbon Dioxide Gas as the Test Fluid", Franklin Institute Report F-A2229, January 1964.

4. J. P. Waggener and W. F. Touchton, "Flow Studies of the AIW-3S Reactor Core Using High Pressure Carbon Dioxide Gas as the Test Fluid", Franklin Institute Report F-B2338, September 1966. 
GENERAL ELECTRIC COMPANY, APO

SOUTHWEST EXPERTMENTAL FAST OXIDE REACTOR (SEFOR)

Why was the model built?

One-half-scale models of the SEFOR reactor were built (a) to study the upper plenum surface wave (to make sure that the core coolant would not sweep cover gas into the circulating system) and (b) for hydraulically studying pressure drop, cross flow, core distribution, vibration, calibration of orifices, and shroud pressure drop. The orifices in the fuel channels in the side above the core permit sodium to "cross flow". This system serves as an emergency cooling route in a main piping failure accident and a thorough study of the cooling flow characteristics was desired. The effect of a baffle plate in the inlet plenum on flow distribution was determined. Orifice pattern requirements were checked out on the total system.

\section{What other models were used?}

A full-scale single-fuel-channel test was used with water as the fluid and with dye injection to obtain a qualitative mixing evaluation of the flow around a fuel rod. A test aimed at quantitative results used a 3 to 1 scale with water as the fluid.

A full-scale single-rod-vibration test was performed.

A full-scale single-channel-heat-transfer test in sodium was also conducted.

A full-scale $60^{\circ}$ core sector of the core channels and clamping mechanism was built to determine clamping loads, channel deflections and the effects of thermal gradients. These studies were performed dry (without liquid fluids) with electrical heaters to give the thermal gradients.

A single-channel sodium-flow test with a full-size channel assembly was used to determine performance of the fuel assembly.

Another system was used to determine the behavior of certain reactor internal structures under thermal shock conditions. This system used sodium to produce temperature shocks from $800^{\circ} \mathrm{F}$ to $1300^{\circ} \mathrm{F}$ and back to $800^{\circ} \mathrm{F}$.

\section{What determined the size of the reactor flow model?}

The choice of 1/2-scale size for the reactor vessel was based primarily on cost with the 1/2-scale size considered a lower point since accuracy problems in mocking up the internals would become difficult. In part the scale selection was made on available equipment to fit the budget. A $1 / 3$ scale was considered but the pressure drop requirements became too high. The model vessel size was based on Reymolds Number similitude and the $1 / 2$-scale model produced a pressure drop of $21 / 2$ to 
3 times that in the prototype; a $1 / 3$ scale would have been higher. The pressure drop increase would have introduced a "lift" change, affecting mechanical characteristics. Also the coolant path between the pressure vessel and shroud for the inlet would be difficult to maintain gap tolerances.

It was believed that Reynolds $n$ umber similitude was important and the scale velocity should not be more than twice normal due to impact factors, etc. There was no attempt to scale tolerances per se in the model. Standard tolerances for the resulting sizes were used. The dimensional and tolerance scale reductions applied to the simulated fuel rods as well as the vessel, channels, etc.

What decided choice of fluid used in the reactor model?

Water was selected for use in the model because of the ability to simulate kinematic viscosity of high temperature sodium by using low temperature water. The use of low temperature water required less elaborate instrumentation and facilitated test operations and model modifications than would be the case with sodium. Also, the cover gas and cold trapping systems required for the liquid metals were not needed in the test loop.

What mixing or data techniques were used?

The water tests, simulating the Froude number of the coolant surface, were conducted using a plexiglass model of the radiation shleld for visual observation.

Pressure taps are the main source of data in the core. Thirteen channels located throughout the core are instrumented with pressure taps to allow calculation of overall loss coefficients and channel entrance coefficients, and to measure core flow in the channels and flow in the extension rods above the cross flow plane.

Vibration measurements on the 1/2-scale shroud are obtained using proximity sensors.

A computer code is used to reduce the test data.

How well did the reactor model work?

Investigations were made of the surface turbulence and potential gas entrainment at the coolant surface in the top plenum of the vessel. Tests conducted early in the design stage with the 1/2-scale model showed excessive turbulence which was eliminated by submerging a plate immediately below the coolant surface. Subsequent testing indicated satisfactory performance and the plate was incorporated into the design of the vessel internal hardware.

At this time (October, 1966) the hydraulic flow model has completed several runs and is still being used for testing. Generally, results obtained from the 1/2-scale test indicate that flow distribution across 
the core is close to the desired curves, but that some minor changes in configuration would be beneficial. Changes which would benefit the flow distribution will be investigated later. Also, the data indicated that the flow through the cross flow holes in the outer channels was higher than expected. A reduction in size or number of holes would be desirable.

The vibration data indicated an incessant vibration which was a selfexcited oscillation arising from shroud absorption of energy from the high friction and local losses of the fluld flow down the narrow annulus between the shroud and vessel. The vibration amplitude is strongly dependent on the flow and increases as the flow to the exponent of f1ve. It is planned to check the vibration in a $1 / 8$-scale model to confirm the extrapolation of the 1/2-scale model to the full scale conditions.

As a result of some of the preliminary test runs in the 1/2-scale model, the scale size was thought to be a sultable selection considering the size of the SEFOR core. A larger core could perhaps utilize a smaller scale.

\section{Overall opinion of General Electric Model Studies}

The 1/2-scale size for the reactor system was adequate for the hydraulic studies and if the studies were to be done over, a smaller scale might be considered. While confirming data is not available from the reactor the actual pressure drops were within $5 \%$ of design estimates. The model testing has shown some areas where reactor design might be improved and has shown a potential vibration problem. (At the time of the visit, only preliminary information was available. Since then, the vibration testing and evaluation has been completed with the $1 / 2-$ scale model as well as a 1/8-scale model bullt to provide an additional check on the vibration characteristics of the design. The results of these tests have been quite favorable and have indicated no vibration problem.)(1) Since the testing with the model vessel has not been completed, several other design changes may be made to benefit the configuration.

Water has been a satisfactory test fluid over the range of temperatures used $\left(90^{\circ} \mathrm{F}\right.$ to $\left.260^{\circ} \mathrm{F}\right)$. Water would be used again if a similar model were to be tested.

FFTF model application

Based on individual coments, it is concluded that hydraulic (water) core testing would be necessary for the FIR, although the specific scale of the model could not be suggested. Other models (single purpose mockups) provide essential data and confirmation, and these would probably be necessary for the program.

I. Letter, I. T. Pedersen from D. R. Riley, May 24, 1967. 
BNWL -518

$-34-$

LOS ALAMOS SCIENIIFIC LABORATORY (IASL)

Fast Reactor Core Test Facility (FRCTF)

The FRCTF was part of the Liquid Metal Fast Breeder Core Test program. The program had as its main objective the testing of prototypical fast reactor core configurations. The test vehicle to accomplish program objectives was to be a 20 megawatt Core Test Facility consisting of prototypical cores and the required heat dissipation system. The reactor heat was to be removed by liquid sodium circulating in a closed primary loop, then transferred by two intermediate heat exchangers to a secondary liquid sodium loop from which the heat was exhausted to the atmosphere by two sodium-to-air heat dumps.

The program was cancelled before completion but some of the major components were completed and tested prior to the cancellation. The intermediate heat exchanger mockup consisted of prototype 5 and $15 \mathrm{Mw}$ heat exchangers of the $\mathrm{Na}$ to $\mathrm{Na}$ varlety. The mockup consisted of stainless steel components with cold water used as the test fluid. All flow testing and vibration testing was done on the actual units after completion of fabrication. Flow rates were carried to $30 \%$ over design. Vibration measurements on the $U$ tubes indicated satisfactory results up to the maximum llow rates. A gas entrainment problem was observed under some conditions on the shell side of the heat exchanger.

A $1 / 10$ sector ( $2 M W$ ) of the origlnally planned FRCIF steam generator (an intermediate heat exchanger and aIr dump were chosen at a later date) was mocked up and successfully proof tested. Sodium was used as the heat fluid with a gas-fired heater as the heat source. There was no observed gas entrainment during steady state flow conditions. However, when flow conditions were changed, It was difficult to adjust gas pressures in the multiple gas volumes correctly, and sometimes gas would transport from one reservoir to another until the pressures were properly balanced. No decrease in heat transfer was observed during these conditions.

Hydraulic testing of the steam generator section was attempted prior to installation to establish flow va. pressure drop data. Flow rates available during the water testing of the steam generator model were high enough to extend slightly into the transition flow regime. These test data were then used to predict operational pressure drops in four different sections of the final steam generator. The superheater and evaporator units were quite similar to the test model and the predicted results were close to measured valves. However, the intermediate heat exchanger and the tempering unit were not well represented by the test model, and the predicted results were misleading.

The criteria used for selecting model size can be reduced to the following:

- Full scale is used wherever possible to minimize the errors inherent in translating data and to permit direct experience with fabrication, installation, and operating characteristics not readily scaleable (vibration, fit, etc.). 
- Economic or available supporting facilitles sometimes dictate scale models or full-scale section use.

- Larger than 1:1 is sometimes used to improve accuracy of results. A 10:I fuel cluster is being considered to improve pressure drop measurement (minimize flow-disturbance from pitot tubes) within the bundle.

- The 1:I size often permits evaluation testing of other prototype components, thereby providing side benefits. When schedules permit, the prototype components are often also used in the final assembly.

Overall opinion of Los Alamos model testing

The modeling and hydraulic testing at Ios Alamos has followed the practice of utilizing full-scale prototypes, which can be installed in the final system, or reduced-scale models (segments) utilizing full-size components to verify hydraulic, mechanical and design characteristics. Preliminary designs and concepts were analyzed by mathemat1cal modeling techniques to determine potential problem areas and to assist in evaluating test results. 
BNWL -518

$-36-$

OAK RIDGE NATIONAL IABORATORY

Homogenous Reactor Test (HRT)

Why was the model built?

The full scale model of the HRT was constructed and used to provide preliminary hydraulic data for the reactor.

What determined the size of the model?

A full scale model was used so interpretation of data would be minimized and accuracy of data would be maximized.

What decided the cholce of fluid used in the model?

Room temperature water was used in the model to achieve near dimensional similarity to uranyl sulfate solution in $\mathrm{D}_{2} \mathrm{O}$, as it was more economical and the testing could be done easier.

Bow well did model data work?

The hydraulic model testing for the HRT was done in two separate and distinct phases. The first phase was done prior to reactor operation and consisted of preliminary hydraulic data. Apparently the limited tests performed were not extensive or intensive enough to identify a sertous problem which caused. holes in the reactor vessel shortly after startup. The holes were caused by a serious chemicalhydraulic problem which allowed the concentration of uranium in solids and a second chemical phase high in uranium to build up heavily in local positions adjacent to the inner vessel wall. This buildup caused high heat fluxes which melted holes in the vessel wall.

The second and most important phase of the model testing was performed after the vessel failure incident to establish what had happened and to determine methods of correcting the problem. (Another model of the reactor was used to establish techniques for making repairs to the vessel through a 2-inch opening in the top of the vessel). By installing a plexiglass section in the flow model it could be seen that the reactor core acted as a classifier (due to the lower velocity in the enlarged diameter) for any particles in the solution. Various schemes were tried on the model to correct the particle holdup in the vessel. The final mode chosen as a result of model testing was to reverse the flow of the fuel solution (now from top to bottom) and to remove most of the baffle plates in the bottom outlet opening of the vessel. In addition, flow was introduced through a jet. The purpose of the changes was to promote better mixing in the vessel and to achieve higher fluid velocities and efficiency of heat removal in the region adjacent to the inner walls. Downflow through the reactor proved to be somewhat successful after reactor startup. Predictions made from data obtained from the model were verified in every case in reactor operation. 
BNWL - 518

$-37-$

What mixing or data techniques were used?

By using colored carbon tetrachloride and gravel (to represent steel oxides or rust) with the original reactor operating conditions, it could be seen from movies taken through the plexiglass that the particles stayed in the screen sections of the reactor for hours. This technique showed what had caused the problem; depostion of uranyl sulfate on the wall causing localized hot spots.

Techniques used for determining temperature instability, chemical instability and flow instability were as follows:

- Mixing and residence time tests used the injection of salt solutions $\left(\mathrm{K}_{2} \mathrm{Cr}_{2} \mathrm{O}_{7}\right)$ and conductivity probes. Transversing probes were used and measurements were made at many positions in the reactor. Heat-mass transfer analogies were used to convert this data into temperature profiles in the Iiquid.

- Boundary layer velocity measurements using Pitot tubes. The conductivity probes cannot be used to measure velocities in the fluid region near the vessel wall. Therefore, the Pitot tube measurements were used to complete the fluid velocity maps of the reactor vessel. These measurements demonstrated that no local concentration build-ups would occur in the wall region. In addition, they were used to calculate temperature profiles near the wall.

- Corrosion rates of vessel walls as effected by temperature and neutron flux were estimated from in and out of pile corrosion experiments performed in small loops. Application of the hydraulic mockup data contributed to relating loop corrosion data to reactor core corrosion information.

- The effect of flow instabilities in the jet on flow distribution and mixing were studied. The inlet jet had produced wobbly flow under certain conditions and it was deemed important to show that this would not be detrimental to reactor operation.

- Proof testing of the letdown system was performed in still another full scale mockup of the entire fuel circulating system. This mockup operated at reactor design temperature and pressure.

\section{Molten Salt Reactor Experiment (MSRE)}

Why were models built?

Two models of the reactor vessel were built. The first was a $1 / 5-$ scale plastic model used as a rough design check for several specific items such as swirl killers, inlet orifice holes, and general flow information, and to provide data for the full-scale model. The second 
$-38-$

model was a full geometrical scale and was used mainly for confirming studies. Both models were started at the same time. The smaller model was completed and tested early enough to incorporate design features into the full-scale model. The smaller model was subsequently abandoned after the full-scale model. was completed. Besides using the full-scale model for hydraulic studies, proof tests of remote maintenance equipment can be done and was one of the intents of the model. To date, however, the model has not been used for that purpose since the reactor has needed no repair.

What determined the size of the models?

The 1/5-scale model was built because it represented dynamic similarity based on velocity. A small-size model was also desired for rough design checks where different designs (such as anti-swirl vanes and orifice holes) could be changed quickly and inexpensively and tested expeditiously. .

The full-scale model was chosen as representing the best size for obtaining the most meaningful and accurate hydraulic data with a minimum of interpretation. The full size was also used for some equipment layout and proof testing of remote maintenance practices, if required.

What determined the cholce of fluid?

Water was used in the hydraulic modeling tests since it has reasonably similar fluid properties at room temperature to the molten salt (mixture of fluoride salts of uranium, lithium berylilum and zirconium) used in the reactor at $1200^{\circ} \mathrm{F}$.

What mixing or data techniques were used?

Flow distribution in the moderator was determined by using an electrolyte injection method. Conductivity probes with cells located fixed distances apart were inserted into each channel. By determining the difference in time of reaction between the cells on a probe, the flow rate versus radial position in the core was determined.

Temperature and velocity profiles in the lower head region were performed with heat meters and Pitot tubes. These tests were performed since oxygen in the fuel might have precipitated oxides on the lower head.

Pressure drops in individual channels were determined using standard methods. The selective deposition of solids in the vessel was determined by dropping metal particles of differing size in the flow stream and visually observing where they are deposited.

Hydraulic vibrations in control rods were visually observed. In addition, studies were made with additives placed in the water (e.g., Jaguar to increase viscosity) to provide a closer simulation of the molten salt. 
BNWL -518

$-39-$

How well did the model data work?

In actual operation of the reactor the results from the hydraulic model were verified in all cases where instrumentation was avaliable in the reactor. There were no major changes of the reactor design as a result of the model studies. The full-scale model is still being kept avallable in case further tests are required or other remote maintenance techniques need to be evaluated.

High Flux Isotope Reactor (HFIR)

Why was the reactor model built?

A full-size mockup of the HFIR was fabricated to obtain hydraulic data, to determine actual equipment locations and to evaluate maintenance techniques for operations support. A lot of gear had to go into the system so the full-scale system was extremely useful to insure against interferences, and to insure that maintenance could be performed on all the equipment.

What determined the size of the model?

The value of full-scale data was deemed extremely important since a minimum of interpretation had to be performed. By using actual size components the clearances required and operational aspects of various pieces of equipment like the control rods could be checked in the facility. Acturl maintenance tools and fixtures could be tested and evaluated on the model.

What decided the cholce of fluid for the model?

Water was used as the model fluid because the reactor used water for cooling and the best data could be obtained with water. Flow rates of 18,000 $\mathrm{gpm}$ were tested in the facility. The flow system for the HFIR model tests was made from carbon steel pipe. The use of carbon steel caused a lot of operating problems due to rust and particles and may have been false economy over the use of a stainless steel system.

Bow well did model data work?

Series of tests were run on parts of the reactor (like the upper plenum) by varying orifice sizes and determine flow rates into control rods and reflector region. Optimum sizes were determined by this method. Tests were made to determine vibration and control rod loads. It was determined that the control rod drives were binding so the installed reactor rod drives were different. The reactor data confirmed the data obtained from the mockup.

Medium Power Reactor Experiment (MPRE)

The MPRE was part of a space program which was cancelled before completion. The system used a boiling potassium Rankin cycle with a one megawatt thermal output. Two mockups containing an array of full-scale simulated fuel elements were built, one using water and the other potassium. 
$-40-$

While it was thought the potassium system was a luxury while being built; as it turned out, it was well worth the money. A full-scale potassium model of the core was planned but the MPRE program was cancelled before It was built.

The use of single vessel with water and then with liquid metal was not judged a good Idea because there were too many problems.

Low Intensity Test Reactor (IIIR)

The IIIR started out as a full scale mockup of the Materlals Testing Reactor and it worked so well that a reactor was made from the model.

\section{Overall oplnion of Dak Ridge model testing}

Full-scale model testing is the preferred method of obtaining hydraulic flow data for complex reactor systems because it represents a minimum of interpretation of data. Smaller-scale models may also be used; but, these in general are used for gross hydraulics and for input into the construction of larger models. Additional benefits to be gained from full-scale models include 1) equipment maintenance techniques can be tested, 2) equipment layouts checked, 3) vibration data can be obtained, 4) fit and clearances can be evaluated, and 5) some of the actual hardware can be proof tested. These factors are judged important enough so full-scale mockups are economically justified.

Water has been the cholce of fluid in almost all cases for reactor modeling because there is no reason to go to more difficult fluids if accurate results can be obtained with water. The techniques and equipment to be used with water are well known and dependable.

In every case (except the first tests done for the HRT) where reactor operation has followed model testing, the model results have been verified in the reactor.

\section{FFIF Model Application}

Based on individual comments, it is concluded that hydraulic (water) core testing would be necessary for the FIR and a full-scale model was suggested. Other models (single purpose mockups) provide essential data and confirmation, and these would probably be necessary for the program. 
BNWL -518

WESTINGHOUSE ELECTRIC CORPORATION, APD

Yankee

Why was the model built?

The 1/12-scale model of the Yankee Reactor was built to obtain hydrodymamic data with four, three and two loop operation to determine pressure drop, flow distribution and mixing. The scale model was built of plastic for visual observation.

Indian Point-2

Why was the model built?

A 1/7-scale model of Indian Point-2 was built to obtaln quantitative data on pressure drop, flow distribution, mixing and semi-quantitative vibration data. The pressure drop and flow distribution in plenums, nozzles and fuel assemblies did not lend themselves to calculations due to the abnormal configurations.

What determined the size of the models?

Four reactor models have been built and tested by Westinghouse at that site. They ranged from an initial 1/12-scale of Yankee to the latest and largest scale of $1 / 7$ for Indian Point-2. The point was made that scale sizes of $3 / 16$ or $1 / 4$ were preferred for entire reactor systems. The choice of what is actually built, however, is determined by the confidence one places in extrapolating particular scale model data to full scale reactor systems. To date, data obtained with 1/7-scale models appear adequate for design purposes, although larger-scale models may give a somewhat higher degree of confidence in the extrapolation. Model costs are considered in establishing the size of the model but in no way limit the model size if technical data can be obtained only in large-scale models.

Exact scaling of models is done on linear dimensions. For reactor systems using packed rod bundles, in which flow mixing between adjacent bundles can occur, exact models of the fuel assemblies are used in the model testing.

What decided choice of fluid used in the models?

Water has been used in the experiments for liquid systems because a fluid more typical of that in the prototype restricts extrapolations, and also most of their previous experience has been with water. Reynolds numbers are not thought to be highly important for pressure losses as long as they are high enough to insure turbulent flow. As a matching flow parameter, concern is mainly with Euler number.

The hydraulic flow system for the reactor model testing is primarily stainless steel to prevent corrosion and rust deposition. 
What mixing or data techniques were used?

Mixing studies were performed by injecting an electrolyte, taking grab samples through the pressure tap lines, and accurately analyzing the samples later in the chemistry laboratory. Temperature streams could be used, but the technique is extremely touchy. Temperature measurement techniques require daily tehermocouple calibration to maintain accuracy and some interpretation has to be done due to heat losses in the system. Dyes were thought to be good for visual studies.

For flow distribution measurements venturis, orifices and Pitot tubes are used. Static pressure measurements are made to determine pressure gradients and equipotential Iines. Usvally a $1 / 4$ sector is fully instrumented and spot checks made on the remaining $3 / 4$ sector.

How well did model data work?

Model data stands by itself. Reactors are not instrumented extensively enough to check predictions based on model behavior. However, with the Yankee reactor model, the measured pressure drop across the vessel correlated within $6 \%$ of the predicted value. Qualitatively, there have been no known reactor problems resulting from model testing inadequacies.

Large-scale (full or near full scale) models may be needed to get vibration data. It is, however, too early to rule out the usefulness of scale-model vibration data. Qualitative vibration information is obtained from the small-scale-model fluid-flow tests.

\section{Overall opinion of Westinghouse Atomic Power Division model testing}

A preferred scale for reactor models was felt to be about $1 / 4$ but satisfactory results could be obtained with smaller models such as $I / 7$. The choice of scale size is tempered by economic considerations. The reactor systems that are being modeled are becoming larger (Indian Point-2 is rated at 2758 muth) and increasing the model sizes represents very large testing facilities.

Water is the preferred model testing fluid for water prototypes because the results require less interpretation and previous testing has indicated satisfactory results using water.

FFTF model applieation

It was suggested a small-scale model be built using gaseous fluid for bench tests and checking design changes and a larger model be built using water for quantitative results.

- For FFTF experiments, in which fuel assemblies are enclosed in tubes, venturis and orifices simulating the fuel assembly flow resistance would be adequate fuel substitutes.

- It was pointed out that thermal mixing is worse for sodium than for water because the eddy diffusivity of sodium is lower than 
$-43-$

that of water. Thus, if the water experiments do not show strong indications of mixing adequacy or inadequacy, it might be necessary to run further experiments using sodium. In these tests, models of specific regions of concern rather than whole systems should be used.

- Full-size models of single components such as fuel assemblies are used by Westinghouse and it was suggested that we use at least a full-size single-tube sodium loop in our FTIF experiments as well as the scale models of systems.

- The use of heated models to look at thermel behavior is not far off and it was suggested that if a large model ( $1 / 2$ to full scale) was bullt, that provisions for heating be put in.

- Westinghouse people don't like sector models, because of boundary effects and possible non-typical flow entrances.

- It was also mentioned that we might want strain gages on the FFIF HCM to measure stress from cross flow on the inlet and outlet of the process tubes. 
VISIT TO PACIFIC NORTHWEST LABORATORY BY CASIMIR PIFRRE ZAIESKI, HEAD, SYNIHESIS AND COORDIINATION SERVICE, SACLAY, FRANCE, UNDER US-EURATOM FAST REACTOR EXCHANTE PROGRAM

Following are remarks on modeling and mockups of the French program as presented by Mr. Zaleski:

- The French FBR Program was started in 1957, Rapsodie in 1958. Rapsodie went critical on January 28, 1967, although the original goal was for 1963. This delay was attributed to delay in mockup testing. The initial program called for mockup testing to confirm design. This program was adhered to even though the test period lengthened and contributed to delay in reactor startup. It was indicated that reactor fuel would not have been available even if mockup testing remained on schedule, and so the mockup testing was not responsible for all the delay.

- A very quick review of engineering mockups was given. The review was primarily mentioning the facilities and including (a) full vessel mockup for thermal shock and handling machine, (b) heat exchange I0op ( $\mathrm{Na}-\mathrm{Na}-\mathrm{Air}$ ). He also mentioned the $5 \mathrm{MW}$ steam generator testing faclilty, and the planned 50-60 MW steam generator facility. The steam generator testing is for future reactors such as Phenix.

- The Phenlx program has no full scale, full assembly mockup as. was built for Rapsodie, but does have or will have many other mockups. These icclude the following:

(a) A $1 / 10$ scale plastic model with water for studylng gross behavior directed to stratification and hydraulics in general. There was no mathematical reason for this scale selection. The $1 / 10$ (of approximately 11.5 meter tank) was economically autable for the purpose.

(b) A more precise model test is ceing considered. The scale being considered is $1 / 3$. This size is based on considerations of what reeds to be simulated, how much extrapolations are required, etc. Mr. Zaleski thought that even $1 / 3$ scale may not be large enough, but then the costs become too high.

(c) Fuel handling machine rotation will be fully tested.

(d) Pumps may require testing although the pump manufacturers do not believe tests are needed.

(e) Steam generators will probably be tested to confirm and make small modification through 5 and $50 \mathrm{MW}$ tests.

(f) Intermediate teat exchangers need to be hydraulically (water) tested. 
(g) Control rods will be subjected to full size tests. Similar tests for Rapsodie proved successful and were not expensive.

(h) Mechanical testing will be supported on a partial scale basis.

$\mathrm{Mr}$. Zaleski indicated that there is very little official release of information on their testing work, but there may be internal reports which are available. 
BNWL - 518

$-46-$

APPENDIX 


\section{$-48-$}

PNL Representatives
JK Anderson
$K D$ Hayden
DI Hovorka
DS Trent

Battelle Memorial Institute - Columbus, Ohio - October 19, 1966

BMI Representatives
JA Eibling
IJ Flanigan

PNL Representatives
JK Anderson
KD Hayden
DI Hovorka
DS Trent

Franklin Institute Research Laboratories - October 18, 1966

FIRL Representatives
GP Wachtell
JP Waggener
$\mathrm{Z}$ Zudans

PNI Representatives
JK Anderson
KD Hayden
DI Hovorka
DS Trent

General Electric Company, Atomic Power Equipment Department - October 13, 1966

GE Representatives
$J$ Cochran
KM Horst
$M$ Joinnson
$R$ Meyers
E Polomik
E Quinn

PNL Representatives

DL Hovorka

KG Toyoda 


\section{APPENDIX}

Following is a list of people contacted at each of the survey sites, the Pacific Northwest Laboratory personnel present and the dates of the visits:

Argonne National Laboratory - October 26, 27, 1966

ANL Representatives
TR Bump
RA Jaross
PA Lottes
H Monson
OS SeIm

PNL Representatives
KD Hayden
DL Hovorka
JM Yatabe

Atomics International - October 11, 12, 1966

AI Representatives
RE Durand
$S$ Sudar
CR Davidson
CG Johnson
P.J Pekrul

PNL Representatives

DL Hovorka

KG Toyoda

Babcock \& W1lcox Research Center - October 20, 1966

B \& W Representatives
RK Allen
TM Campbell
CE Jones
$\mathrm{JH}$ Kidwell
RA Lee
HH Poor
JR Schmidt
JS Slotnik 
$-49-$

Los Alamos Scientific Laboratory - September 26, 1966

IASL Representatives
H Bowers
$R$ Clark
W Cooper
B Goplan
H Kraig
A Sullivan
E Swickard
I Whinery
W Wykoff

PNL Representatives

DL Hovorks

IT Pedersen

Oak R1dge Nat1onal Laboratory - October 24, 25, 1966

ORIL Representatives
SE Beall
A Grendell
RM Hill
HW Hoffman
RJ Kedl
WH Kelley
CG Lawson
RE MacPherson
I Spiewak

PNL Representatives
KD Hayden
DL Hovorka
JM Yatabe

Westinghouse Atomic Power Division - October 21, 1966

WAPD Representatives

RT Berringer

AA Bishop

AF Kitzes
PNL Representatives
JK Anderson
KD Hayden
DL Hovorka

Casimir Plerre Zaleski - February 16, 1967

PNL Representatives

IM Finch

RE Peterson

KG Toyoda 
BNWL -518

DISTRIBUTION

Argonne National Laboratory

RA Jaross

LMFBR Program office

Atomic Energy Commission, Washington

Division of Reactor Development and

Technology

$M$ Shaw, Director, RDT

Asst Dir for Nuclear Safety

Analys is \& Evaluation Br,RDT:NS

Environmental \& Sanitary Engrg,RDT:NS

Research \& Development Br,RDT:NS

Asst Dir for Plant Engrg, RDT

Applications \& Facilities Br,RDT:PE

Components $\mathrm{Br}, \mathrm{RDT}: \mathrm{PE}$

Instrumentation \& Contro1 Br, RDT: PE

Systems Engrg $\mathrm{Br}$, RDT:PE

Asst Dir for Program Analysis, RDT

Asst Dir for Project Mgmt,RDT

Liquid Metals Projects Br, RDT: PM

FFTF Project Manager,RDT:PM (3)

Asst Dir for Reactor Engineering

Control Mechansisms $\mathrm{Br}, \mathrm{RDT}: \mathrm{RE}$

Core Design Br, RDT:RE

Fue 1 Fabrication $\mathrm{Br}, \mathrm{RDT}: \mathrm{RE}$

Fuel Handling $B r, R D T: R E$

Reactor Vesse1s Br, RDT:RE

Asst Dir for Reactor Technology

Chemistry \& Chemical Separations $\mathrm{Br}, \mathrm{RDT}: \mathrm{RT}$ (2)

Fuels \& Materials Br,RDT:RT

Reactor Physics Br, RDT:RT

Special Technology $\mathrm{Br}, \mathrm{RDT}: \mathrm{RT}$

Idaho Operations Office

CW Bills, Director

Richland Operations Office

DE Crouter (2)

JH Krema

San Francisco Operations Office Director, Reactor Division

AEC - Office of Senior Site Rep. (PNL)
AEC - Office of Senior RDT Site Rep Atomics International Argonne National Laboratory Atomic Power Development Assoc. General Electric

Atomics International

LE Glasgow

RW Dickinson

KW Foster

Atomic Power Development Assoc. BVD Farris

Babcock \& Wilcox Company TM Campbe11, Jr

SH Esleeck

TP Farrel1

Battelle Memorial Institute

Columbus Laboratories

JA Eibling

Douglas-United Nuclear DL Hovorka

Franklin Institute Research Lab. $J$ Pendelton Waggener

General Atomic Division (SAN) D Coburn (2)

Genera1 Electric Company Dr K Cohen (3)

DR Riley

B Wolfe

Idaho Nuclear Corporation DR deBoisblanc

Los Alamos Scientific Lab. WR Wykoff

Oakridge National Lab. I Spiewak

Stanford University Dr R Sher

Westinghouse Electric Corp. DR JCR Kelly

AS Kitzes 
Batte1le Northwest
WG Albert
ER Astley
DL Ballard
JM Batch.
RA Bennett
JR Boldt
CL Boyd
DC Boyd
CL Brown
WL Bunch
CP Cabe 11
WE Cawley
WL Chase
TT Claudson
PD Cohn
DL Condotta
JM Davidson
DR Doman
GE Driver
RV Dulin
JF Erben
LM Finch
SM Gil1
RA Harvey
KD Hayden (5)
BR Hayward
JW Helm
RJ Hennig
GM Hesson
PL Hofmann
BM Johnson
HG Johnson
RL Junkins
JH Kinginger
MR Kreiter
DD Lanning
HD Lenkersdorfer
$\mathrm{CW}$ Lindenmeier
HE Little
WW Little
CE Love
WB McDonald
MH Meuser
RA Moen
CA Munro
DM Nero

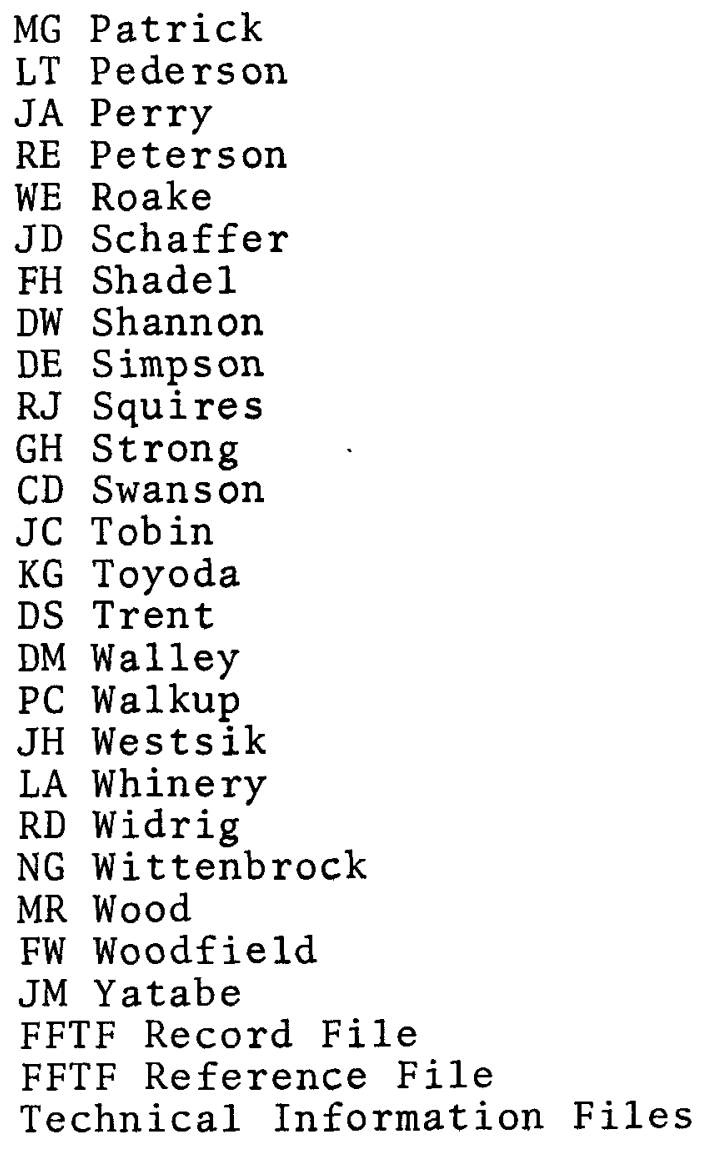

